\title{
Regional differences in modelled net production and shallow remineralization in the North Atlantic subtropical gyre
}

\author{
B. Fernández-Castro ${ }^{1}$, L. Anderson ${ }^{2}$, E. Marañón ${ }^{1}$, S. Neuer ${ }^{3}$, B. Ausín ${ }^{1}$, M. González-Dávila ${ }^{4}$, J. \\ M. Santana-Casiano ${ }^{4}$, A. Cianca ${ }^{4}$, R. Santana ${ }^{4}$, O. LLinás ${ }^{5}$, M. J. Rueda ${ }^{6}$, and B. Mouriño-Carballido ${ }^{1}$ \\ ${ }^{1}$ Departamento de Ecoloxía e Bioloxía Animal, Universidade de Vigo, Vigo, Pontevedra, 36200, Spain \\ ${ }^{2}$ Applied Ocean Physics and Engineering Department, Woods Hole Oceanographic Institution, Woods Hole, \\ MA 02543-1541, USA \\ ${ }^{3}$ School of Life Sciences, Arizona State University, Tempe, AZ 85287-4501, USA \\ ${ }^{4}$ Universidad de Las Palmas de Gran Canaria (ULPGC), Campus Universitario de Tafira s/n., \\ 35017 Las Palmas de Gran Canaria, Spain \\ ${ }^{5}$ Plataforma Oceánica de Canarias (PLOCAN), Crta. de Taliarte s/n, P.O. Box 413, 35200 Telde, Gran Canaria, Spain \\ ${ }^{6}$ Instituto Canario de Ciencias Marinas, Gobierno de Canarias, Telde, Gran Canaria, Spain
}

Correspondence to: B. Fernández-Castro (bieito.fernandez@uvigo.es)

Received: 5 December 2011 - Published in Biogeosciences Discuss.: 22 December 2011

Revised: 15 May 2012 - Accepted: 30 June 2012 - Published: 1 August 2012

\begin{abstract}
We used 5-yr concomitant data of tracer distribution from the BATS (Bermuda Time-series Study) and ESTOC (European Station for Time-Series in the Ocean, Canary Islands) sites to build a 1-D tracer model conservation including horizontal advection, and then compute net production and shallow remineralization rates for both sites. Our main goal was to verify if differences in these rates are consistent with the lower export rates of particulate organic carbon observed at ESTOC. Net production rates computed below the mixed layer to $110 \mathrm{~m}$ from April to December for oxygen, dissolved inorganic carbon and nitrate at BATS $\left(1.34 \pm 0.79 \mathrm{~mol} \mathrm{O}_{2} \mathrm{~m}^{-2},-1.73 \pm 0.52 \mathrm{~mol} \mathrm{C} \mathrm{m}^{-2}\right.$ and $-125 \pm 36 \mathrm{mmol} \mathrm{N} \mathrm{m}^{-2}$ ) were slightly higher for oxygen and carbon compared to ESTOC $\left(1.03 \pm 0.62 \mathrm{~mol} \mathrm{O}_{2} \mathrm{~m}^{-2}\right.$, $-1.42 \pm 0.30 \mathrm{~mol} \mathrm{C} \mathrm{m}^{-2}$ and $-213 \pm 56 \mathrm{mmol} \mathrm{N} \mathrm{m}^{-2}$ ), although the differences were not statistically significant. Shallow remineralization rates between 110 and $250 \mathrm{~m}$ computed at ESTOC $\left(-3.9 \pm 1.0 \mathrm{~mol} \mathrm{O}_{2} \mathrm{~m}^{-2}, 1.53 \pm 0.43 \mathrm{~mol} \mathrm{C} \mathrm{m}^{-2}\right.$ and $38 \pm 155 \mathrm{mmol} \mathrm{N} \mathrm{m}^{-2}$ ) were statistically higher for oxygen compared to BATS $\left(-1.81 \pm 0.37 \mathrm{~mol} \mathrm{O}_{2} \mathrm{~m}^{-2}, 1.52 \pm\right.$ $0.30 \mathrm{~mol} \mathrm{C} \mathrm{m}^{-2}$ and $147 \pm 43 \mathrm{mmol} \mathrm{N} \mathrm{m}^{-2}$ ). The lateral advective flux divergence of tracers, which was more significant at ESTOC, was responsible for the differences in estimated oxygen remineralization rates between both stations. According to these results, the differences in net production
\end{abstract}

and shallow remineralization cannot fully explain the differences in the flux of sinking organic matter observed between both stations, suggesting an additional consumption of nonsinking organic matter at ESTOC.

\section{Introduction}

The ocean is responsible for an annual photosynthetic fixation of $\sim 50 \mathrm{Pg}$ of carbon, which represents around half of the global primary production (Field et al., 1998). Carbon fixation by marine phytoplankton and its transport to the deep ocean, known as the biological carbon pump, plays a key role in the ocean-atmosphere $\mathrm{CO}_{2}$ exchange, and hence affects climate on time-scales from decades to thousands of years. The carbon pump efficiency is not constant and depends on several factors, such as the input of nutrients into the euphotic layer, and the balance between synthesis and remineralization of organic matter as well as the planktonic community composition.

Subtropical gyres represent the central part of the ocean and are characterized by a strong stratification of the water column. This translates into a weak input of nutrients into the euphotic layer and, as a consequence, low phytoplankton biomass and productivity. Because of their 
oligotrophic characteristics, they have been traditionally considered oceanic deserts. However, from the point of view of carbon export from the euphotic zone, subtropical gyres were found to be surprisingly productive (Emerson et al., 1997). This fact, combined with their vast extension $(\sim 60 \%$ of the total ocean surface), results in their contribution of at least $30 \%$ of total marine new production (Najjar and Keeling, 2000).

The North Atlantic subtropical gyre (NASG) is one of the best studied open ocean regions, and in the past decades, it has been a major contributor to the development of our understanding of biogeochemical cycles in subtropical regions. Traditionally, subtropical gyres have been considered relatively constant ecosystems in time and space. However, the comparative study of time-series data revealed that spatial heterogeneity is important in understanding the biogeochemistry of this biome (Neuer et al., 2002a; Mouriño-Carballido and Neuer, 2008). Two time-series stations, BATS (Bermuda Atlantic Time-series Study, $31.7^{\circ} \mathrm{N}-64.2^{\circ} \mathrm{W}$ ) and ESTOC (European Station for Time series in the Ocean, Canary Islands, $29.16^{\circ} \mathrm{N}-15.5^{\circ} \mathrm{W}$ ), are located at about the same latitude in the western (NASW) and eastern (NASE) portions of NASG. The monthly sampling program was initiated in October 1988 at BATS and in February 1994 at ESTOC, with the aim of tracking seasonal, inter-annual and inter-decadal changes in several biogeochemical variables (Steinberg et al., 2001; Neuer et al., 2007). Although both stations exhibit typical oligotrophic characteristics, they are characterized by different hydrographic dynamics. BATS is located in the recirculation of the Gulf Stream and it is strongly affected by mesoscale activity (Cianca et al., 2007). ESTOC is entrained by the Canary Current and is indirectly influenced by the coastal African upwelling, whichs exports nutrients and organic matter towards the center of the gyre by means of upwelling filaments and Ekman transport (Pelegrí et al., 2005; Álvarez-Salgado et al., 2007). It is important to note that upwelling filaments do not influence ESTOC directly (Davenport et al., 2002), and this station is considered oligotrophic based on nutrient scarcity, phytoplankton biomass and production rates (Neuer et al., 2007).

Although both stations are characterized by similar phytoplankton biomass and primary production rates, annual mean carbon export measured by using sediment traps at 150, 200 and $300 \mathrm{~m}$ is significantly lower at ESTOC, by a factor of 35, than at BATS (Neuer et al., 2002a; Helmke et al., 2010). Assuming that the euphotic zone is in steady state, higher export production should be sustained by larger inputs of nutrients and/or organic matter into the euphotic zone. It has been proposed that differences in the nutrients input could be due to the more intense mesoscale activity observed at BATS (Siegel et al., 1999; Mouriño et al., 2003). A comparative study using 10-yr BATS and ESTOC data combined with satellite altimetry data indicated that the higher physical forcing dominant at BATS - deeper mixed layers and more intense mesoscale dynamics - is partly compensated by the shallower nutricline observed at ESTOC (Cianca et al., 2007). According to these authors, NASE receives $\sim 75 \%$ of the nutrients avaliable for new production at NASW, although this difference is not statistically significant. Another source of new nitrogen that could explain the observed differences in carbon export between the two stations is biological nitrogen fixation. Recent studies indicate that this process supplies a significative contribution to total new nitrogen inputs in oligotrophic waters (Capone et al., 2005; MouriñoCarballido et al., 2011; Bonnet et al., 2011). Biogeochemical estimates suggest a lower contribution of nitrogen fixation at ESTOC compared with BATS (Neuer et al., 2002a).

The differences observed between the two stations in export rates of particulate organic carbon could also be a consequence of differences in the remineralization rates of the sinking organic matter. The comparative analysis of respiration rates determined from in vitro oxygen evolution experiments conducted in the NASE and NASW indicated higher oxygen consumption rates in the eastern part (MouriñoCarballido and Neuer, 2008). It has been shown that atmospheric dust deposition can strongly stimulate bacterial respiration (Pulido-Villena et al., 2008). A recent study demonstrated that the most frequent and intense response of the microbial plankton to atmospheric dust deposition in the Tropical Atlantic is the stimulation of the bacterial activity rather than phytoplankton primary production (Marañón et al., 2010). This is consistent with the results found at ESTOC, which is strongly influenced by the natural atmospheric deposition of Saharan dust, and where phytoplanktonic production seems not to be affected by aerosol inputs (Neuer et al., 2004).

For the first time, concomitant data of tracer distribution from the BATS and ESTOC time-series sites were analysed and used to build up a 1-D tracer conservation diagnostic model. The model was used to compute net production and shallow remineralization rates at both sites. The main goal of this study was to verify if differences in the synthesis and consumption of organic matter could explain the lower export rates of particulate organic carbon observed at ESTOC.

\section{Comparison of the seasonal cycles at BATS and ESTOC}

Monthly climatologies were calculated for temperature, salinity, density anomaly $\left(\sigma_{T}\right)$, oxygen, dissolved inorganic carbon (DIC), nitrate (actually nitrate+nitrite) and chlorophyll $a$, using the BATS and ESTOC data collected for the period 1996-2001 (Fig. 1). The BATS data were obtained from the BATS Web site (http://bats.bios.edu). BATS and ESTOC measurements were made monthly except during the spring bloom period at BATS (February-April) when biweekly samplings were conducted. Methodologies and results have been reported earlier for BATS (Michaels and Knap, 1996; Steinberg et al., 2001) and ESTOC (Neuer et al., 

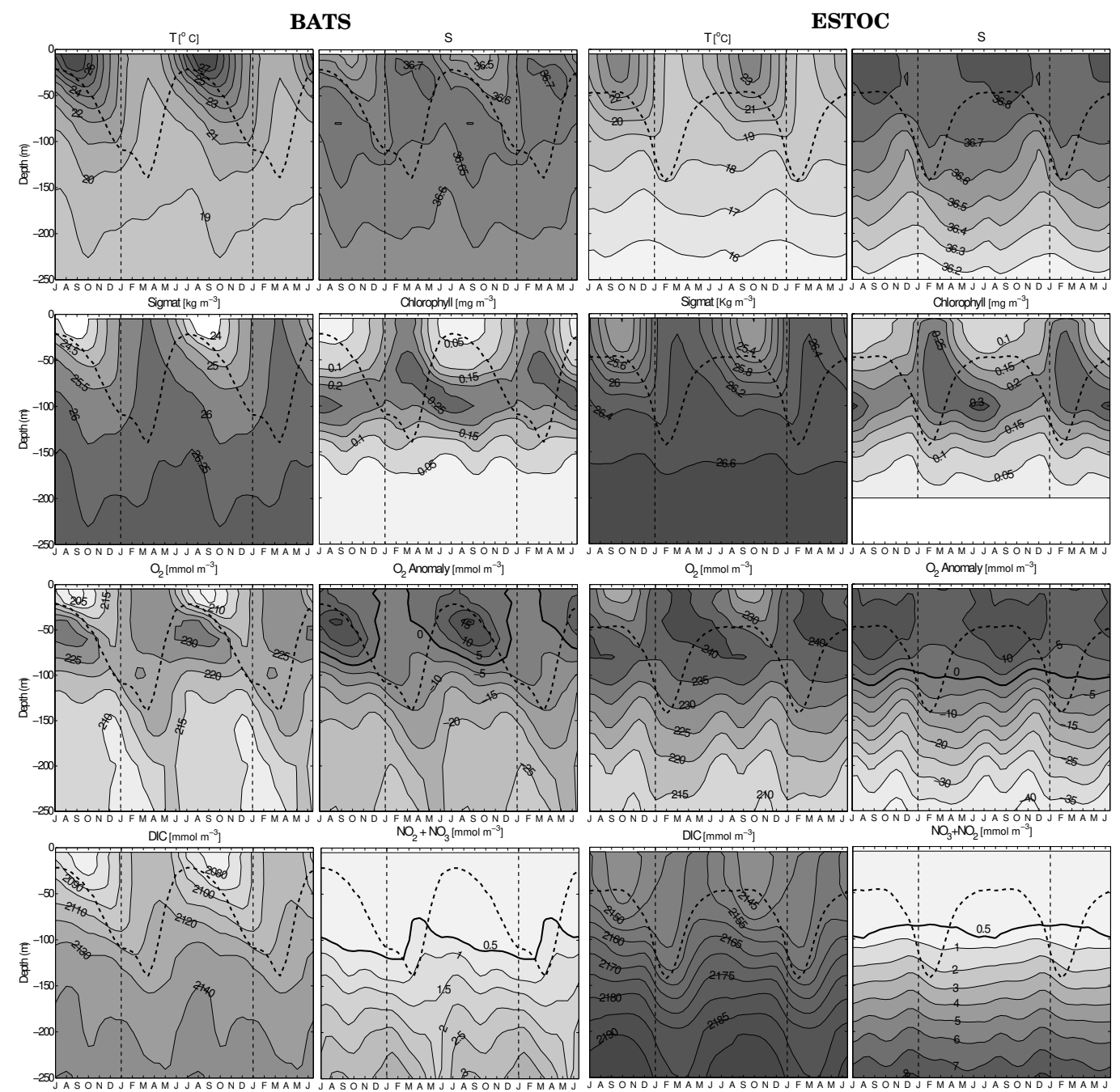

Fig. 1. Seasonal cycles of the vertical distribution of temperature $\left({ }^{\circ} \mathrm{C}\right)$, salinity (psu), density anomaly $\sigma_{T}\left(\mathrm{~kg} \mathrm{~m}^{-3}\right)$, chlorophyll $a$ (mg $\left.\mathrm{m}^{-3}\right)$, nitrate + nitrite $\left(\mathrm{mmol} \mathrm{m}^{-3}\right)$, oxygen $\left(\mathrm{mmol} \mathrm{m}^{-3}\right)$, oxygen anomaly $\left(\mathrm{mmol} \mathrm{m}^{-3}\right)$ and dissolved inorganic carbon (DIC) $\left(\mathrm{mmol} \mathrm{m}{ }^{-3}\right)$. Black discontinuous line represents the mixed layer depth. Black thick line represents the isoline of zero oxygen anomaly and the nitracline $\left(\left[\mathrm{NO}_{3}\right]=0.5 \mathrm{mmol} \mathrm{m}^{-3}\right)$.

2007). Discrete data were first interpolated to a grid with the following depths: $5,10,20,40,60,80,100,110,120,140$, 160,200 and $250 \mathrm{~m}$. The mean annual cycle was then constructed by averaging data from each depth onto a temporal grid of 15 days using a weighted moving average with a normal weighting factor, $f_{i}^{n}$, and a window of 50 days:

$$
\begin{aligned}
& \left\langle C^{n}\right\rangle=\sum_{i} f_{i}^{n} C_{i} / \sum_{i} f_{i}^{n} \\
& f_{i}^{n}=\exp \left[-\left(\frac{t^{n}-t_{i}}{\sigma}\right)^{2}\right],
\end{aligned}
$$

where $C$ is the averaged variable, $t$ is the time of the year in days (0-365), $i$ is the index of the discrete data point, $n$ is the index for the temporal grid and $\sigma=35$ days is a constant time scale. The mixed layer depth was calculated as the depth where temperature differs $0.1^{\circ} \mathrm{C}$ from the $10 \mathrm{~m}$ value.
BATS and ESTOC exhibit a similar seasonality in the hydrographic conditions characterized by a period of winter mixing from November to March, followed by a period of summer stratification from May to September (Fig. 1). The maximum winter mixing occurs later (mid-March) at BATS compared to ESTOC (February). The transition between both periods is controlled by the seasonal cycle of solar irradiation and changes in the wind speed. Seasonality is more intense at BATS, where surface temperature increases from a minimum of $\sim 20^{\circ} \mathrm{C}$ in mid-March to a maximum of $\sim 28^{\circ} \mathrm{C}$ in August. At ESTOC, temperatures reach a minimum of 18 $19^{\circ} \mathrm{C}$ in February and a maximum of $\sim 24^{\circ} \mathrm{C}$ in September. This maximum appears later than at BATS because the intensification of the trade winds affects the ESTOC site during the summer period. Maxima mixed layers are deeper at BATS $(193 \pm 26 \mathrm{~m})$ than at ESTOC $(146 \pm 32 \mathrm{~m})$. Summer 
stratification is also more intense at BATS, where mixed layers during this period reach $\sim 20 \mathrm{~m}$. Mixed layers at ESTOC extend to a depth of $\sim 50 \mathrm{~m}$ due to the trade winds intensification that enhances mixing during July-August. The main difference between both stations in salinity appears during the summer, when mixed layer values are fresher at BATS due to the rain intensification.

Chlorophyll concentration is strongly influenced by the physical forcing at both stations. Phytoplankton blooms occur in late winter/early spring, after the mixed layer extends below the nutricline, with greatest monthly values of chlorophyll concentration similar for both stations (ca. $0.3 \mathrm{mg} \mathrm{m}^{-3}$ ). As water column stratification increases, surface chlorophyll decreases and a deep chlorophyll maximum establishes at ca. $100 \mathrm{~m}$ at BATS and ESTOC. This biological activity as well as the physical forcing determine the concentration of the chemical tracers considered in this study.

The oxygen seasonal cycle in the mixed layer at both stations is characterized by maximum values during the winter period due to the increase in solubility. The temperature increase during the summer months causes a drop in solubility and hence in surface oxygen concentration. As stratification increases during summer, oxygen accumulates below the mixed layer ( $\sim 40 \mathrm{~m}$ at BATS and $\sim 60 \mathrm{~m}$ at ESTOC). This accumulation is clearly pictured by the oxygen anomaly distribution that represents the excess of oxygen concentration above the solubility equilibrium. The oxygen anomaly distribution shows that whereas the photic layer (ca. $100 \mathrm{~m}$ at both sites, Cianca et al., 2007) at ESTOC is oversaturated during the whole year, at BATS it is undersaturated during the winter period. This difference is probably due to the different intensity in the mixing and ventilation of deep waters that characterizes both stations. The seasonal variability in the oxygen cycle is also weaker at ESTOC, where the maximum amplitude of the accumulation in oxygen anomaly below the mixed layer was $\sim 9 \mathrm{mmol} \mathrm{m}^{-3}$ (from February to August), versus $\sim 17 \mathrm{mmol} \mathrm{m}^{-3}$ (from February to September) at BATS. The oxygen anomaly distribution in the euphotic zone has a mirror-like image below this layer. Oxygen concentration increases during winter-spring as a result of the mixing with oxygen-rich surface waters and it is maximum in April-May. Then, during summer stratification oxygen concentration decreases, with the minimum values observed in January (BATS) and November (ESTOC) at $200 \mathrm{~m}$. Despite the differences observed in the euphotic zone, the maximum amplitude of the oxygen signal at $200 \mathrm{~m}\left(\sim 7 \mathrm{mmol} \mathrm{m}^{-3}\right)$ is similar in both stations.

DIC concentrations in the mixed layer are greatest in April (BATS) and March (ESTOC), due to mixing with deeper waters and, to a lesser extent, to air-sea exchange (Marchal et al., 1996; Gruber et al., 1998; González-Dávila et al., 2003). Surface DIC concentrations decline to minimum values in October, this decline being more pronounced at BATS $\left(\sim 44 \mathrm{mmol} \mathrm{m}^{-3}\right)$ compared to ESTOC $\left(\sim 15 \mathrm{mmol} \mathrm{m}^{-3}\right)$. Below the euphotic zone, DIC accumulation occurs in con- cert with the observed oxygen decline. The DIC accumulation at $200 \mathrm{~m}$ from April to January (BATS) and from April to October (ESTOC) is $6 \mathrm{mmol} \mathrm{m}^{-3}$ and $8.7 \mathrm{mmol} \mathrm{m}^{-3}$, respectively.

Nitrate concentration is very low in the euphotic zone at both stations. The nitracline $\left(>0.5 \mathrm{mmol} \mathrm{m}^{-3}\right)$ is generally shallower at ESTOC $(90.3 \pm 5.0 \mathrm{~m})$ compared to BATS $(104 \pm 14 \mathrm{~m})$, but with a greater vertical variability at the western station. As a consequence of the influence of the nutrient poor $18^{\circ} \mathrm{C}$ Subtropical Mode Water at BATS, nitrate concentration below the nitracline is higher at ESTOC. Below the euphotic zone, nitrate accumulates from June to January at BATS and from May to December at ESTOC; the amplitude of the accumulation at $200 \mathrm{~m}$ is very similar in both stations $\left(0.7 \mathrm{mmol} \mathrm{m}^{-3}\right)$.

The seasonal variability of the tracers considered in this study, in agreement with previous reports for BATS (Menzel and Ryther, 1959; Jenkins and Goldman, 1985; Marchal et al., 1996) and ESTOC (González-Dávila et al., 2003; Neuer et al., 2007; Santana-Casiano et al., 2007), is consistent with the fact that synthesis of organic matter occurs in the euphotic layer and that this matter is remineralized, at least partially, in the shallow aphotic zone between 100$250 \mathrm{~m}$. In order to quantify the contribution of the biological processes and the physical forcing to the observed seasonal variability of the chemical tracers, a 1-D diagnostic model was implemented.

\section{Model implementation}

\subsection{Model general description}

We adapted the tracer conservation model based on Ono et al. (2001), who estimated the shallow remineralization at BATS for the period 1992-1998. This approach includes the main physical processes that occur below the mixed layer when convective winter mixing is not the dominant process. These processes are vertical diffusion, vertical advection (Ekman transport) and lateral advection. We used the following tracer conservation equation

$\frac{\partial C}{\partial t}=-u \frac{\partial C}{\partial x}-v \frac{\partial C}{\partial y}-w \frac{\partial C}{\partial z}+K \frac{\partial^{2} C}{\partial z^{2}}+J_{C}$

where $C=C(t, z)$ represents temperature $(T)$ or the tracer (oxygen, DIC, nitrate) concentration for each depth, $z$, and time $t ; u(t, z)$ and $v(t, z)$ are the longitudinal and latitudinal geostrophical velocities, respectively; $\partial C / \partial x$ and $\partial C / \partial y$ are the longitudinal and latitudinal gradients of temperature and tracer concentration; $K(t)$ is the vertical diffusivity, and $J_{C}(t, z)$ represents the sources minus sinks term. For temperature, $J_{C}$ represents the effect of the solar shortwave radiation that penetrates below the mixed layer depth; whereas for oxygen, DIC and nitrate it represents the net effect of 

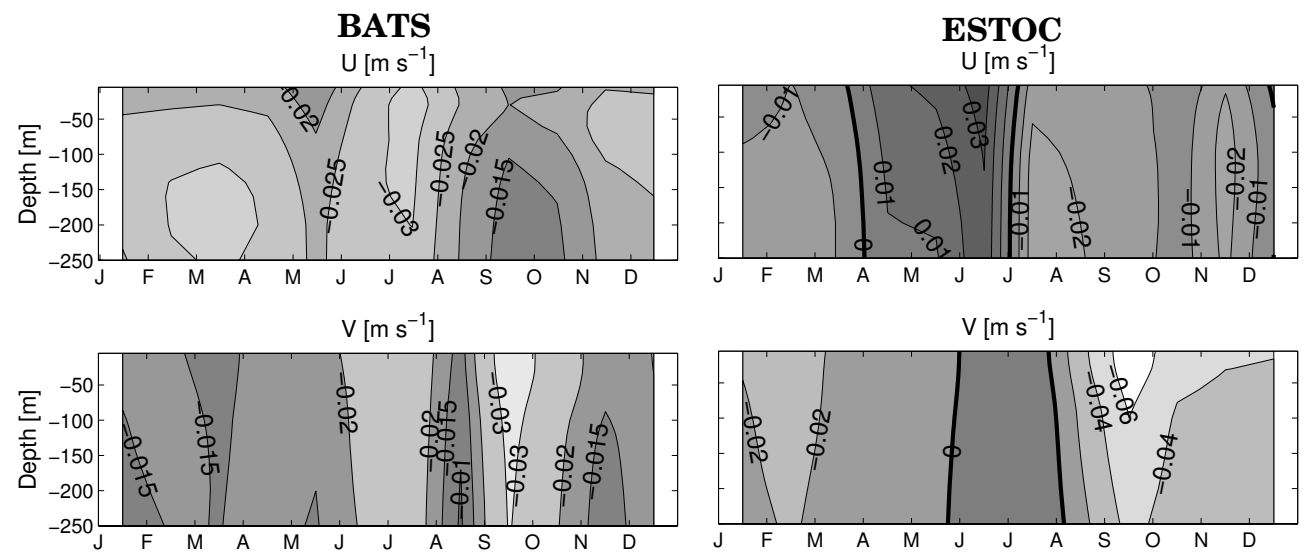

Fig. 2. Computed geostrophic horizontal velocities $(u, v)$ for BATS and ESTOC. The thick black line represents the null velocity component.

photosynthesis and respiration, and therefore net production and shallow remineralization.

The model was executed 23 times for each variable in periods of 15 days during the seasonal cycle, with a time step $\mathrm{d} t=0.005$ days and an uniform vertical grid $(\mathrm{d} z=1 \mathrm{~m})$ from the mixed layer depth to $250 \mathrm{~m}$. In each of these runs the model was initialized with the profile of the tracer for the initial time $t, C^{\mathrm{obs}}(t, z)$, and produces the modelled profile for the final time $t+\Delta t, C^{\text {model }}(t+\Delta t, z)$, where $\Delta t=15$ days. For the biological tracers $J_{C}$ was computed diagnostically, as described by Mouriño-Carballido and Anderson (2009), so that the output of the model for each run fits the profile for the corresponding final time. An initial guess for the $J_{C}(t, z)$ term was made as $\left(C_{\text {obs }}(t+\Delta t, z)-C_{\text {obs }}(t, z)\right) / \Delta t$. The model was run forward from time $t$ to time $t+\Delta t$ and a mean squared misfit was computed as:

Cost $=\left(\int_{\text {MLD }}^{250 \mathrm{~m}}\left(C_{\mathrm{obs}}(t+\Delta t, z)-C_{\bmod }(t+\Delta t, z)\right)^{2} d z\right)^{1 / 2}$

When the difference of Cost with the previous estimate was less than $0.002 \mathrm{mmol} \mathrm{m}^{-2}$, the simulation was ended and the simulation of the next 15-day period was initiated. Otherwise, $J_{C}(t, z)$ was corrected as:

$J_{C}^{\text {new }}(t, z)=J_{C}(t, z)+0.75\left(C_{\mathrm{obs}}(t+\Delta t, z)-C_{\bmod }(t+\Delta t, z)\right) / \Delta t$,

and a new run was conducted. In this way, $J_{C}(t, z)$ was optimized so that $C^{\mathrm{mod}}(t+\Delta t, z)$ fits $C^{\mathrm{obs}}(t+\Delta t, z)$.

In order to compute the biological source term $\left(J_{C}\right)$, tracer data, horizontal and vertical velocities were calculated as described below and linearly interpolated to the model grid.

\subsection{Model inputs}

\subsubsection{Horizontal advection}

Horizontal gradients of temperature, oxygen and nitrate were calculated using the four grid points surrounding BATS and
ESTOC at the World Ocean Atlas 2009 monthly climatology (WOA09) (Locarnini et al., 2010; Garcia et al., 2010b,a). Longitudinal and latitudinal gradients were computed using averaged values for each $\mathrm{x}$ - and $\mathrm{y}$-components. DIC data for the same locations were obtained from the Global Distribution of Total Inorganic Carbon and Total Alkalinity Below the Deepest Winter Mixed Layer Depths climatology (Goyet et al., 2000), which includes lower temporal resolution trimonthly averaged data.

Horizontal velocities, $u$ and $v$, were assumed to be geostrophic and computed from the monthly temperature and salinity WOA09 data (Locarnini et al., 2010; Antonov et al., 2010) and the thermal wind equations. Water density was calculated using the Millero and Poisson (1981) parametrization. The thermal wind equations were integrated down to $3000 \mathrm{~m}$, which was assumed as the level of no motion following Siegel and Deuser (1997). The calculated geostrophic flow for BATS $\left(0.02-0.04 \mathrm{~m} \mathrm{~s}^{-1}\right)$ was directed southwest during the whole year (see Fig. 2), consistent with the fact that BATS is influenced by the Gulf Stream recirculation (Siegel and Deuser, 1997; Ono et al., 2001). The flow intensity was more variable near ESTOC $\left(0.02-0.07 \mathrm{~m} \mathrm{~s}^{-1}\right)$, where the current was directed southwest during most of the year except between March and April, when $u$ was eastward, and during the transition from spring to summer (May-July) when $v$ was northward. This pattern is consistent with the results described by Neuer et al. (2007) and Pelegrí et al. (2005).

Due to the implementation imposed to ensure volume conservation (see next section), lateral transport included a nongeostrophic component. Further on we will use geostrophic horizontal advection to refer to the geostrophic component of the lateral transport and horizontal advection to refer to the total corrected lateral transport.

Additionally, model runs where the geostrophic transport term was set to zero $(u=v=0)$ were used to determine the 
influence of the geostrophic transport in the computed biological rates.

\subsubsection{Vertical advection}

Ekman downwelling/upwelling velocity, $w$, was computed for both stations from the wind stress monthly climatological data included in the International Comprehensive OceanAtmosphere Data Set, with a spatial resolution of $2^{\circ} \times 2^{\circ}$ (Leetmaa and Bunker, 1978). The computed Ekman velocity at BATS was negative during most of the year and characterized by a clear seasonal cycle (see Fig. 3a). Downwelling was maximum in February $\left(-96 \mathrm{~m} \mathrm{yr}^{-1}\right)$ and minimum in September, when a weak upwelling was computed $\left(10 \mathrm{~m} \mathrm{yr}^{-1}\right)$. These results are in agreement with the harmonic function used by Musgrave et al. (1988) and Ono et al. (2001) at BATS. The Ekman velocity was lower at ESTOC, where the seasonal cycle was characterized by relatively weak upwelling during the summer (ca. $20 \mathrm{~m} \mathrm{yr}^{-1}$ ) and relatively weak downwelling during the rest of the year.

The Ekman velocity was set to zero at the surface and increased linearly to the Ekman depth, which was considered as the minimum value of $30 \mathrm{~m}$ and the mixed layer depth, and decreased linearly to zero down to $250 \mathrm{~m}$ (Ono et al., 2001). As the depth-dependent $w$ requires horizontal convergence or divergence for volume conservation, horizontal advection included a correction term. This was accomplished numerically by implicitly evaluating $w \partial C / \partial z$ at the grid box interfaces.

\subsubsection{Shortwave solar radiation}

The effect of the solar shortwave radiation that penetrates below the mixed layer ( $J_{C}$ term for the temperature model) was computed as:

$J_{C}^{T}(t, z)=\frac{1}{\rho(t, z) C_{p}(t, z)} \frac{\partial I(t, z)}{\partial z}$,

where $\rho$ is the water density computed from temperature and salinity seasonal cycles using the Millero and Poisson (1981) formulation, $C_{p}$ is the specific heat (Fofonoff and Millard, 1983), and $I(t, z)$ is the shortwave radiation flux computed by using the attenuation model of Paulson and Simpson (1977) for Type I water and the surface shortwave radiation values (Fig. 3b). These values were obtained by fitting to an harmonic function monthly data for the period 1996-2001 obtained from the CORE.2 Global Air-Sea flux dataset close to both sites. Annual means and amplitudes of the harmonic function were $182 \pm 5 \mathrm{~W} \mathrm{~m}^{-2}$ and $87 \pm 6 \mathrm{~W} \mathrm{~m}^{-2}$ at BATS, and $191 \pm 5 \mathrm{~W} \mathrm{~m}^{-2}$ and $68 \pm 8 \mathrm{~W} \mathrm{~m}^{-2}$ at ESTOC, respectively. Surface $I$ was minimum in January for both stations.
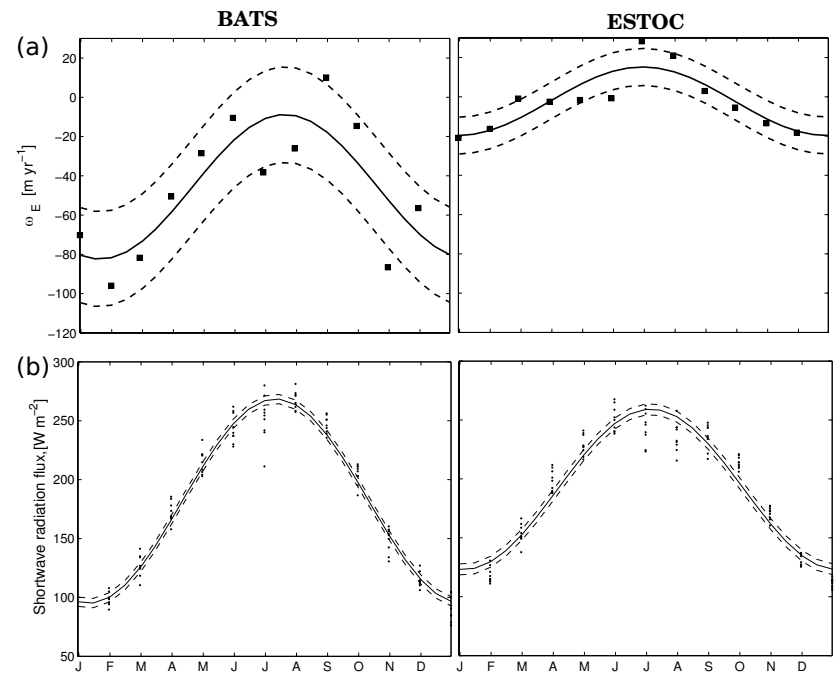

Fig. 3. (a) Vertical Ekman velocity $(w)$ at the Ekman depth $\left(w_{\mathrm{E}}\right)$ and (b) surface shortwave solar radiation computed for the period 1996-2001 near BATS and ESTOC. The continuous lines represent the fit to a single harmonic function, whereas the dotted line correspond to the $95 \%$ confidence intervals. Fitting of $w_{\mathrm{E}}$ to the harmonic function was not used in the model.

\subsection{Temperature model and $K$ optimization}

Similar to the approach followed by Musgrave et al. (1988), Ono et al. (2001) and Mouriño-Carballido and Anderson (2009), we computed the vertical diffusivity $(K)$ from the optimization of the simulated temperature $(T)$ seasonal cycle (Fig. 4). An optimized value of $K$ was obtained every 15 days by minimizing the following function for each run:

$\operatorname{Cost}(t)=\left(\int_{\operatorname{MLD}(t)}^{250 \mathrm{~m}}\left(T_{\mathrm{obs}}(t, z)-T_{\bmod }(t, z)\right)^{2} d z\right)^{1 / 2}$.

The annual mean $K$ was $2.0 \pm 1.5 \mathrm{~cm}^{2} \mathrm{~s}^{-1}$ for BATS and $1.5 \pm 1.6 \mathrm{~cm}^{2} \mathrm{~s}^{-1}$ for ESTOC. The maximum $K$ at BATS was set to $5 \mathrm{~cm}^{2} \mathrm{~s}^{-1}$ on account of numerical limitations in the biological source term calculations due to the high values computed during the winter mixing. At ESTOC, higher K-values were computed in July and August, possibly related to trade wind intensification during the summer months.

The comparison of the temperature rate of change computed from the observed and simulated seasonal cycles showed a good agreement for both stations (Fig. 5). The errors in the simulation of the temperature seasonal cycle were computed as:

$\operatorname{Err}(t, z)=\operatorname{abs}\left(\frac{T_{\mathrm{mod}}(t, z)-T_{\mathrm{obs}}(t, z)}{T_{\mathrm{obs}}(t, z)}\right)$.

Model errors were related to a deficient parametrization of the constant vertical diffusivity, especially during strong 


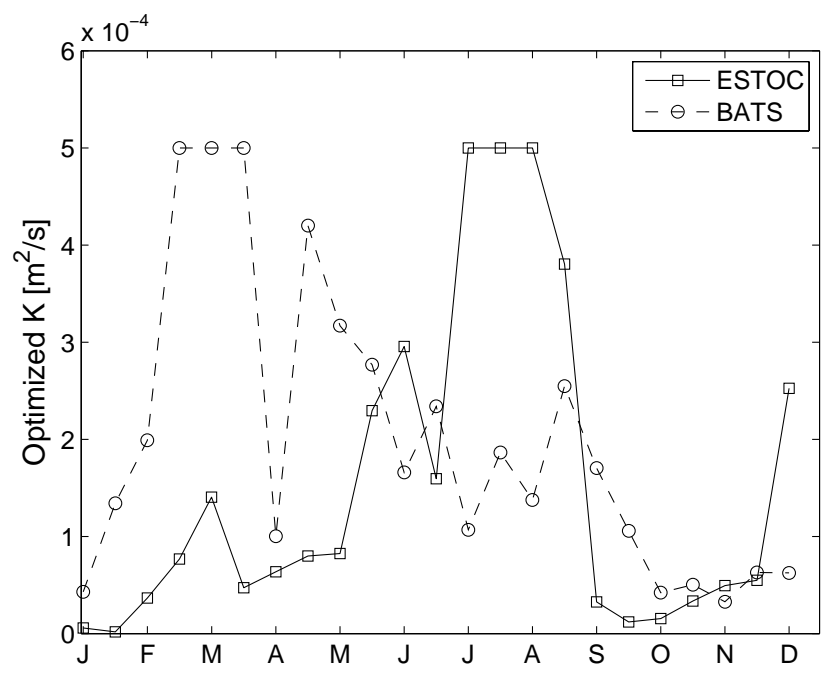

Fig. 4. Optimized diffusivity $(K)$ computed for BATS and ESTOC. Values higher than $5 \mathrm{~cm}^{2} \mathrm{~s}^{-1}$ where set to $5 \mathrm{~cm}^{2} \mathrm{~s}^{-1}$ on account of numerical limitations in the biological source term calculations.

mixing events. Higher errors were computed during the periods of strong winter mixing for both stations, just below the mixed layer in June-July (BATS) and August-September (ESTOC), and between 100 and $250 \mathrm{~m}$ in September at BATS and June-September at ESTOC. Ono et al. (2001) used a single $K$ optimized for the whole year; however, we observed that optimizing $K$ for each 15-day period reduced the total integrated error in the simulation of the temperature seasonal cycle by $13 \%$ at BATS and $20 \%$ at ESTOC (data not shown). Figure $5 \mathrm{~d}$ shows the contribution of the geostrophic horizontal advection to the temperature rate of change. This contribution was more important at ESTOC, where an input of warmer water was computed in June-July and colder water in September.

\subsection{Integrated budgets and errors estimation}

Net production rates below the mixed layer were computed by integrating the biological source term $\left(J_{C}\right)$ from this depth to the estimated compensation depth. This depth was set to $110 \mathrm{~m}$ based on the $J_{C}$ distribution and the examination of rates sensitivity to this limit (see below). To compute shallow remineralization, $J_{C}$ was integrated from the compensation depth down to $250 \mathrm{~m}$. Both rates were integrated between April and December in order to avoid the period of intense and intermittent winter mixing, which is not accurately simulated by the model. The physical model terms were also integrated for the same period and depth intervals to evaluate their contribution to the change in the tracer inventories.

Uncertainties associated with the integrated budgets were estimated by using Monte Carlo simulations. A high number $(N>100)$ of model runs for all the tracers (including temperature for $K$ optimization) were performed with each
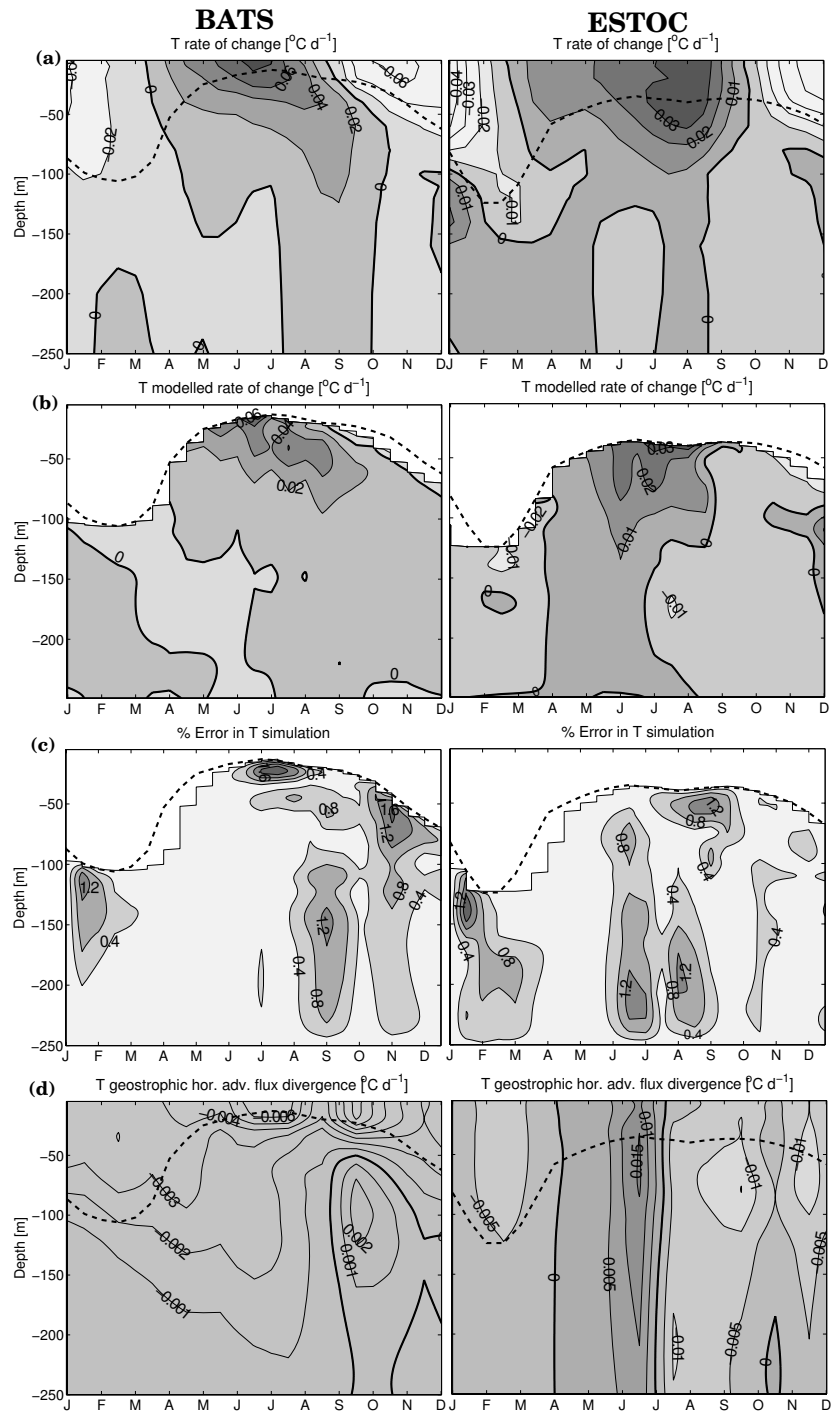

Fig. 5. (a) Observed and (b) simulated temperature rate of change, (c) errors in the simulated temperature seasonal cycle, and (d) geostrophic horizontal advection flux divergence at BATS and ESTOC. The black discontinuous line represents the mixed layer depth and the black thick line represents the zero rate of change isoline.

element of the model inputs being randomly generated from a Gaussian distribution. The standard deviation of the Gaussian distribution was taken from the estimated error of the model inputs. The weighted standard error was used for the seasonal cycles of temperature and the chemical tracers, the standard error provided by the WOA09 data base was used for the variables obtained from this climatology, and a $75 \%$ error was assigned to the DIC lateral gradients - consistent with the magnitude of computed errors for the lateral gradients of oxygen and nitrate. For the Ekman velocity $(w)$, the error considered was $25 \%$ according to Ono et al. (2001). The uncertainties associated with the integrated budgets were 

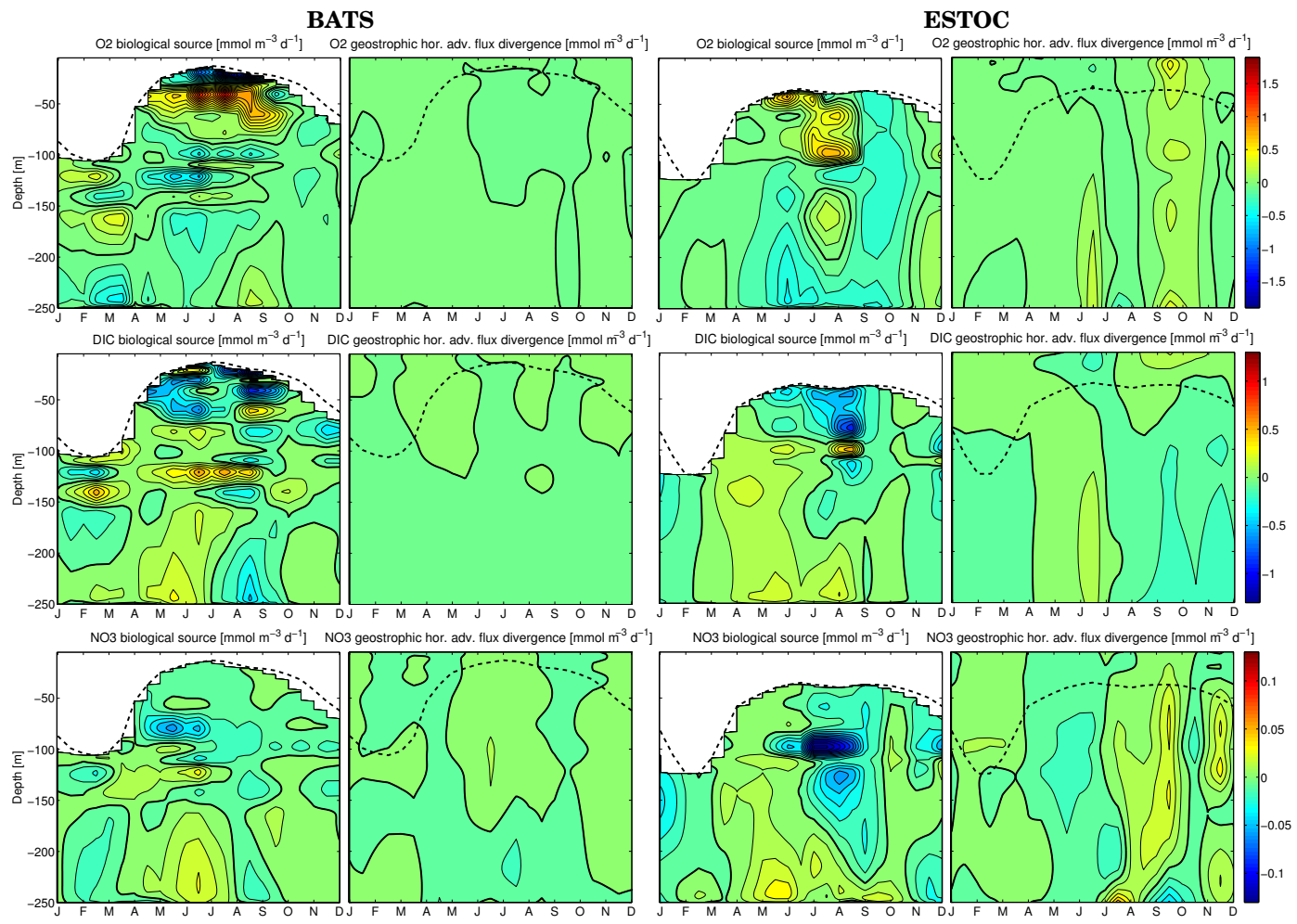

Fig. 6. Biological source term $\left(J_{C}\right)$ and geostrophic horizontal advection flux divergence computed for oxygen, DIC and nitrate at BATS and ESTOC. The discontinuous line represents the mixed-layer depth and the black thick line the zero isoline. Isoline separations are $0.1 \mathrm{mmol}$ $\mathrm{O}_{2} \mathrm{~m}^{-2} \mathrm{~d}^{-1}, 0.1 \mathrm{mmol} \mathrm{C} \mathrm{m}^{-2} \mathrm{~d}^{-1}$ and $0.01 \mathrm{mmol} \mathrm{N} \mathrm{m}^{-2} \mathrm{~d}^{-1}$, for oxygen, DIC and nitrate, respectively.

the standard deviation of the values of the integrated budgets produced by each model realization.

\section{Results and discussion}

\subsection{Distribution of biological sources and sinks}

Figure 6 shows the biological source term $\left(J_{C}\right)$ computed for oxygen, DIC and nitrate by using the diagnostic model at BATS and ESTOC and the geostrophic horizontal flux divergence (i.e. the contribution of the geostrophic horizontal advection to the total rate of tracer change).

Despite the signal being noisier, probably due to using a shorter data set and a time-dependent $K$ optimization, the distribution of $J_{C}$ computed for all the tracers at BATS was in general agreement with the results reported by Ono et al. (2001). The biological oxygen (DIC and nitrate) production (consumption) computed below the mixed layer was consistent with the synthesis of organic matter, whereas oxygen (DIC and nitrate) consumption (production) computed in the shallow aphotic zone indicated remineralization of organic matter. Oxygen production occurred below the mixed layer during summer stratification with the maximum at ca. $40 \mathrm{~m}$. The compensation depth $\left(J_{C}=0\right)$ was between $80-100 \mathrm{~m}$. Below the compensation depth, maximum oxygen consump- tion was computed at ca. $120 \mathrm{~m}$ during late spring and early summer. The high oxygen consumption computed just below the mixed layer coincided with large errors in the temperature simulation (see Fig. 5c), which are probably related to limitations in the diffusivity optimization. DIC consumption ocurred just below the mixed layer during summer stratification. For this tracer the compensation depth was slightly shallower (ca. 60-80 m), and maximum production was computed at $120 \mathrm{~m}$ during the summer. The distribution of $J_{C}$ for nitrate was very similar to DIC but the compensation depth was located deeper (ca. 110-115 m). Maximum nitrate consumption was computed at $80 \mathrm{~m}$ during May-June. Maximum production occurred at $120 \mathrm{~m}$, coinciding with the maximum rates of DIC (oxygen) production (consumption), and slightly shallower than the maximum described by Ono et al. (2001) at $140 \mathrm{~m}$. A second maximum in nitrate remineralization was observed at $250 \mathrm{~m}$ close to the model border.

The distribution of $J_{C}$ at ESTOC was in general very similar to the patterns described for BATS, although a few differences were observed. The oxygen compensation depth was located deeper at ca. $115 \mathrm{~m}$. Highest rates of oxygen production were also located deeper (ca. $100 \mathrm{~m}$ ), coinciding with the deep chlorophyll maximum. The vertical structure of the spring-summer remineralization was also different compared to BATS, as highest rates - instead of being located at 
specific depths - occurred through out the whole water column. Another important difference with BATS was observed in September-November when high oxygen (DIC, nitrate) consumption (production) was computed through the whole water column. This feature coincided with significant inputs of oxygen and nitrate, and also cold water (Fig. 5d), through horizontal advection. The role of the horizontal transport in the seasonality of the synthesis and remineralization of organic matter has been previously reported in the Canary region, which is under the influence of the coastal African upwelling (Neuer et al., 2002b; Arístegui et al., 2003; Pelegrí et al., 2005; Alonso-González et al., 2009). Upwelling filaments and Ekman transport export particulate and dissolved organic matter from the coastal upwelling to the open ocean. During this transport organic matter is remineralized, at least partially, providing an external source for nutrients (Pelegrí et al., 2005). According to these authors, the relevance of this process is higher during the fall. These facts indicate that at ESTOC, even though removed from direct influence of the upwelling zone, allochthonous inputs of organic and inorganic matter could represent sources and sinks for oxygen, DIC and nutrients that must be considered when interpreting our model results.

\subsection{Net production rates}

We set $110 \mathrm{~m}$ as the mean compensation depth because it is the approximate depth of maxima in the integrated net production and remineralization rates for nitrate and for oxygen at ESTOC (see Fig. 7). DIC and oxygen at BATS actually have maxima at $80-90 \mathrm{~m}$, but they all have inflection points near $110 \mathrm{~m}$, and the $110 \mathrm{~m}$ integrals are not greatly different (20\% lower for DIC at ESTOC and O2 at BATS; $2 \%$ lower for DIC at BATS). Net production rates and all the integrated model terms, including the associated errors computed below the mixed layer to $110 \mathrm{~m}$ from April to December for both stations, are shown in Fig. 8.

Net production rates computed for oxygen (1.34 \pm $\left.0.79 \mathrm{~mol} \mathrm{O}_{2} \mathrm{~m}^{-2}\right)$, dissolved inorganic carbon $(-1.73 \pm$ $\left.0.52 \mathrm{~mol} \mathrm{C} \mathrm{m}^{-2}\right)$ and nitrate $\left(-125 \pm 36 \mathrm{mmol} \mathrm{N} \mathrm{m}^{-2}\right)$ at BATS were slightly higher for oxygen and carbon compared to ESTOC $\left(1.03 \pm 0.62 \mathrm{~mol} \mathrm{O}_{2} \mathrm{~m}^{-2},-1.42 \pm 0.30 \mathrm{~mol} \mathrm{C} \mathrm{m}^{-2}\right.$ and $-213 \pm 56 \mathrm{mmol} \mathrm{N} \mathrm{m}^{-2}$ ), although the differences were not statistically significant. In agreement with previous geochemical estimates (Riser and Johnson, 2008), our results indicate that in these regions, at least for the depths (mixed layer base to $110 \mathrm{~m}$ ) and time period (April-December) we considered, photosynthesis exceeds remineralization of organic matter.

The comparison of the observed changes in the tracer inventories and the modelled net production evidences the relevance of the physical fluxes, as the change in the tracers, in general, underestimated biological net production. The change in the tracer inventories underestimated oxygen net production rates by $163 \%$ at BATS and $136 \%$ at ESTOC.

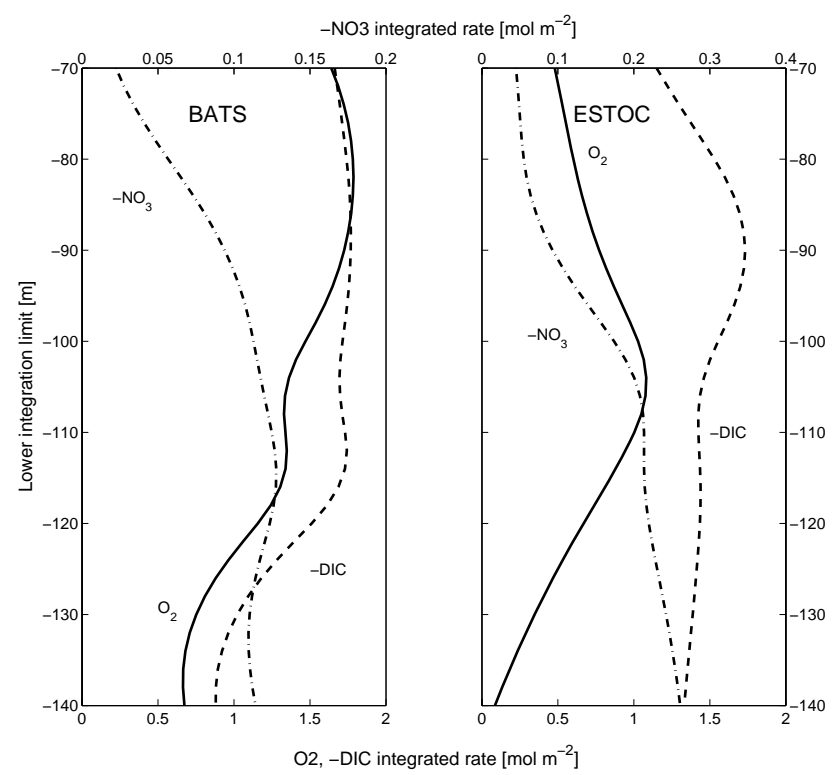

Fig. 7. Time and depth-integrated net production rates as a function of the lower limit used for the integration at BATS and ESTOC for oxygen (solid), DIC (dashed) and nitrate (dot-dashed).

For DIC the underestimation was $63 \%$ at ESTOC, whereas it was overestimated by $17 \%$ at BATS. For nitrate the underestimation was $97 \%$ at BATS and $102 \%$ at ESTOC. The contribution of diffusion was larger than total advection (horizontal + vertical) for all the tracers at both stations except DIC at BATS.

Computed net production rates compared with a summary of previous values reported for BATS and ESTOC are presented in Table 1, where different integration periods must be interpreted carefully. Gruber et al. (1998) and Brix et al. (2006) estimated that net production at BATS during the spring-summer period represents $60-80 \%$ of the total annual net production. Similar results were obtained at ESTOC by González-Dávila et al. (2003). As the integration interval (April-December) used for our estimates misses part of the winter-spring bloom (Brix et al., 2006; González-Dávila et al., 2007, 2010), our rates are probably lower than annual estimates. According to Marchal et al. (1996), net production in the mixed layer in the Sargasso Sea represented $60 \%$ of the photic layer net production. Assuming this is also true for ESTOC, our rates would represent about $40 \%$ of the total net production, i.e. $3.4 \mathrm{~mol} \mathrm{O}_{2} \mathrm{~m}^{-2}$ and $-4.3 \mathrm{~mol} \mathrm{C} \mathrm{m}^{-2}$ at BATS, and $2.6 \mathrm{~mol} \mathrm{O}_{2} \mathrm{~m}^{-2}$ and $-3.6 \mathrm{~mol} \mathrm{C} \mathrm{m}^{-2}$ at ESTOC. As nitrate consumption is only observed in the lower photic layer, this extrapolation is not suitable for this tracer. Using an oxygen tracer model, Musgrave et al. (1988) estimated the rate of net production in the photic layer at BATS to be $3-4 \mathrm{molO}_{2} \mathrm{~m}^{-2} \mathrm{yr}^{-1}$, very similar to our estimate $\left(3.4 \mathrm{~mol} \mathrm{O}_{2} \mathrm{~m}^{-2}\right)$. Our rate for net production of carbon at BATS $\left(1.73-4.3 \mathrm{~mol} \mathrm{C} \mathrm{m}^{-2}\right)$ is in the range of previous estimates using mixed layer model approaches (1.8- 
Table 1. Summary of net production estimates reported for BATS and ESTOC. MLD is the mixed-layer depth.

\begin{tabular}{|c|c|c|c|c|c|}
\hline Region & Source & Technique & Period & Depths & $\begin{array}{l}\text { Estimate } \\
\text { mol m}^{-2}\end{array}$ \\
\hline Sargasso Sea & Musgrave et al. (1988) & Tracer model & Annual & Photic Layer (PL) & $3-4\left(\mathrm{O}_{2}\right)$ \\
\hline BATS & Marchal et al. (1996) & Mixed-layer model & Mar-Oct & Extrapolation PL & $1.8-2.9(\mathrm{C})$ \\
\hline BATS & Gruber et al. (1998) & Mixed-layer model & Annual & Mixed Layer & $2.3 \pm 0.9(\mathrm{C})$ \\
\hline BATS & Brix et al. (2006) & Mixed-layer model & Annual & PL & $4.9 \pm 0.3(\mathrm{C})$ \\
\hline BATS & Siegel et al. (1999) & Nitrogen budget & Annual & PL & $0.48 \pm 0.12(\mathrm{~N})$ \\
\hline Sargasso Sea & Lipschultz et al. (2002) & $\mathrm{N}$ budget & Annual & PL & $0.37-1.39(\mathrm{~N})$ \\
\hline BATS & Cianca et al. (2007) & $\mathrm{N}$ budget & Annual & PL & $0.38 \pm 0.08(\mathrm{~N})$ \\
\hline BATS & This study & Tracer Model & Apr-Dec & MLD to $110 \mathrm{~m}$ & $\begin{array}{l}1.34 \pm 0.79\left(\mathrm{O}_{2}\right) \\
1.73 \pm 0.52(\mathrm{C}) \\
0.125 \pm 0.036(\mathrm{~N})\end{array}$ \\
\hline ESTOC & González-Dávila et al. (2003) & Mixed-layer model & Mar-Oct & Mixed Layer & $1.55 \pm 0.75(\mathrm{C})$ \\
\hline ESTOC & González-Dávila et al. (2007) & Mixed-layer model & Annual & Mixed Layer & $3.3 \pm 0.8(\mathrm{C})$ \\
\hline ESTOC & Cianca et al. (2007) & $\mathrm{N}$ budget & Annual & PL & $0.28 \pm 0.09(\mathrm{~N})$ \\
\hline ESTOC & This study & Tracer Model & Apr-Dec & MLD to $110 \mathrm{~m}$ & $\begin{array}{l}1.03 \pm 0.62\left(\mathrm{O}_{2}\right) \\
1.42 \pm 0.30(\mathrm{C}) \\
0.213 \pm 0.053(\mathrm{~N})\end{array}$ \\
\hline
\end{tabular}

\section{BATS}
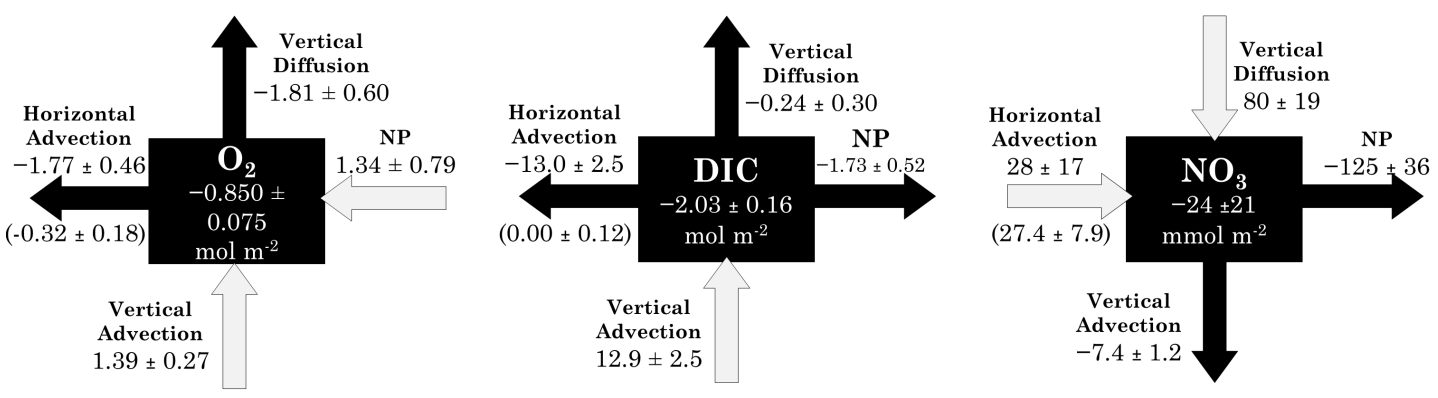

ESTOC
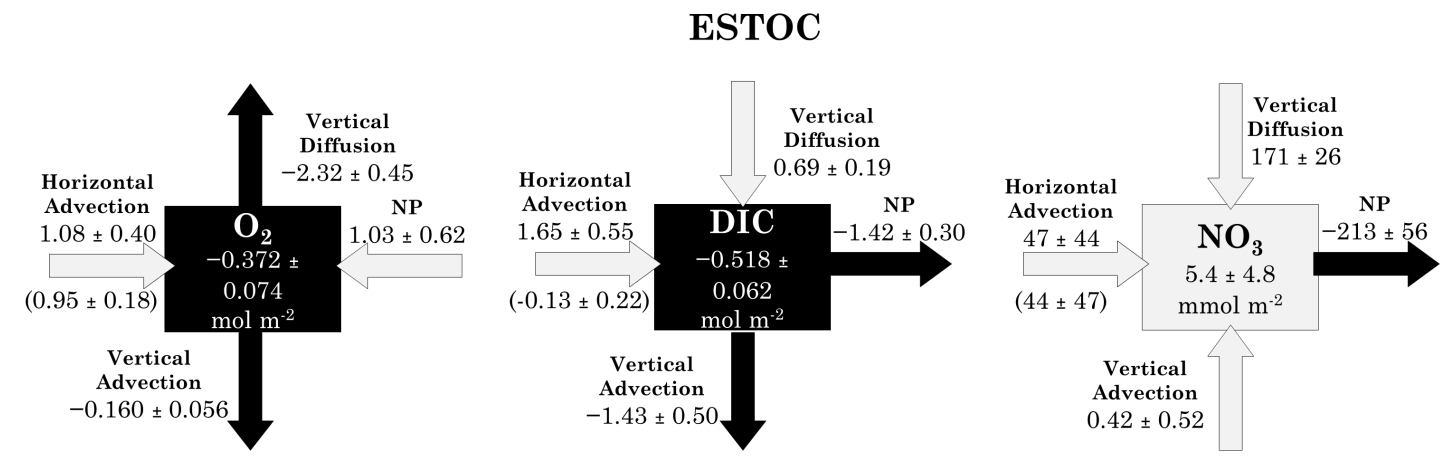

Fig. 8. Integrated model terms computed from the mixed layer depth to $110 \mathrm{~m}$, and from April to December. NP is net production. Integrated geostrophic horizontal advection term is shown in brackets. The white (black) arrows and boxes represent net gain (lost). Rates are expresed in $\mathrm{mol} \mathrm{m}^{-2}$ for oxygen and DIC and in $\mathrm{mmol} \mathrm{m}^{-2}$ for nitrate. 
4.0 $\mathrm{mol} \mathrm{C} \mathrm{m}^{-2}$, Marchal et al., 1996; Gruber et al., 1998; Brix et al., 2006). A compilation of nitrogen inputs carried out in the Sargasso Sea including wet and dry deposition, convective, diapycnal and isopycnal mixing, Ekman transport, mesoscale eddies and nitrogen fixation quantified annual production in $0.37-1.39 \mathrm{~mol} \mathrm{~N} \mathrm{~m}^{-2} \mathrm{yr}^{-1}$ (Lipschultz et al., 2002). Our estimate for net production of nitrogen at BATS $\left(0.125 \pm 0.036 \mathrm{~mol} \mathrm{~N} \mathrm{~m}^{-2}\right)$ - which neglects important sources of nitrogen as nitrogen fixation, convective mixing and mesoscale structures - does not reach the lower end of this compilation. Our estimate is also lower than the value obtained by Siegel et al. (1999) $(0.48 \pm 0.12 \mathrm{~mol} \mathrm{~N}$ $\mathrm{m}^{-2} \mathrm{yr}^{-1}$ ), who reported a compilation of new nitrogen inputs where nitrogen fixation was not included.

González-Dávila et al. (2003), by using a mixed-layer model for ESTOC that did not include lateral advection, estimated net production of carbon in the mixed layer between April and October for the period 1996-2001 to be $25.5 \pm 5.7 \mathrm{mmol} \mathrm{C} \mathrm{m}^{-3}$. This value corresponds to a mixed layer net production rate of $1.55 \pm 0.75 \mathrm{~mol} \mathrm{C} \mathrm{m}^{-2}$, computed considering the averaged depth of the mixed layer during this period $(61 \pm 26 \mathrm{~m})$. Following the same approach but using a longer data set (1995-2004), González-Dávila et al. (2007) estimated net production in the mixed layer to be $3.3 \pm 0.8 \mathrm{~mol} \mathrm{C} \mathrm{m}^{-2}$. Both rates are in close agreement with our estimate $\left(1.42-3.6 \mathrm{~mol} \mathrm{C} \mathrm{m}^{-2}\right)$. Our rate of net production based on nitrate $(0.213 \pm 0.053 \mathrm{~mol} \mathrm{~N} \mathrm{~m}-2)$ is only slightly lower than the total new nitrogen inputs reported by Cianca et al. (2007) at ESTOC $\left(0.28 \pm 0.09 \mathrm{~mol} \mathrm{~N} \mathrm{~m}^{-2}\right.$ $\mathrm{yr}^{-1}$ ), who considered eddy pumping, convective, diapycnal and isopycnal mixing, and Ekman transport.

The $-\mathrm{O}_{2}: \mathrm{C}$ ratios computed from the net production estimates at BATS $(0.77 \pm 0.51)$ and ESTOC $(0.72 \pm 0.46)$ are lower than the ratio for $\mathrm{NO}_{3}$-based production (1.4, Gruber (2008)) and closer to the ratio for $\mathrm{NH}_{4}$-based production (1.1). The lower $-\mathrm{O}_{2}: \mathrm{C}$ ratio at ESTOC could be related to the remineralization peak observed during the fall (September-November), which was more intense for oxygen than for DIC, probably due to the larger lateral inputs (see Fig. 6). When the biological source term at ESTOC was integrated between April and September, excluding the remineralization pulse observed in autumn, the $-\mathrm{O}_{2}: \mathrm{C}$ ratio $(1.30 \pm 0.62)$ was closer to the standard values. Net production rates computed between April and December with the geostrophic model term set to zero (see Sect. 3.2.1) gave a $-\mathrm{O}_{2}: \mathrm{C}$ ratio of $\sim 1.0$, also in better agreement with the canonic values. At BATS, we attributed the low $-\mathrm{O}_{2}: \mathrm{C}$ ratio to the diffusion simulation that causes a strong oxygen consumption between the mixed-layer depth and $35 \mathrm{~m}$. If this region was not included in the integration, oxygen production rate would be increased $\left(2.14 \pm 0.37 \mathrm{~mol} \mathrm{O}_{2} \mathrm{~m}^{-2}\right)$ and DIC production rate lowered $\left(-1.20 \pm 0.21 \mathrm{~mol} \mathrm{C} \mathrm{m}^{-2}\right)$, resulting in higher than Redfield ratio $(1.78 \pm 0.86)$. The $\mathrm{C}: \mathrm{N}$ value at BATS $(13.9 \pm 5.8)$ was higher than the Redfield ratio (6.6) and very similar at ESTOC $(6.7 \pm 2.3)$. However, this is slightly deceiving in that most of the oxygen production and DIC uptake occurs above $80 \mathrm{~m}$, while most of the $\mathrm{NO}_{3}$ uptake occurs between $80-110 \mathrm{~m}$, which is not constant Redfield $\mathrm{C}$ : $\mathrm{N}$ coupling.

\subsection{Remineralization rates}

All the model terms were integrated between April and December and $110-250 \mathrm{~m}$ to obtain shallow remineralization rates (see Fig. 9). Oxygen $\left(-1.81 \pm 0.37 \mathrm{~mol} \mathrm{O}_{2} \mathrm{~m}^{-2}\right.$ ) and DIC $\left(1.52 \pm 0.30 \mathrm{~mol} \mathrm{C} \mathrm{m}^{-2}\right)$ remineralization rates computed for BATS were in good agreement with those reported by Ono et al. (2001) $\left(-2.08 \pm 0.38 \mathrm{~mol} \mathrm{O}_{2} \mathrm{~m}^{-2}\right.$ and $-1.53 \pm 0.35 \mathrm{~mol} \mathrm{C} \mathrm{m}^{-2}$ ), whereas nitrate remineralization rate $\left(147 \pm 43 \mathrm{mmol} \mathrm{N} \mathrm{m}^{-2}\right)$ was twice the rate reported by these authors $\left(80 \pm 46 \mathrm{mmol} \mathrm{N} \mathrm{m}^{-2}\right)$. This mismatch was due to the differences in the geostrophic lateral advection term $\left(-51 \pm 44 \mathrm{mmol} \mathrm{N} \mathrm{m}^{-2}\right.$ versus $39 \pm 39 \mathrm{mmol} \mathrm{N} \mathrm{m}^{-2}$ reported by Ono et al.) that resulted from the use of different climatologies. Changes in the tracer inventories also underestimated shallow remineralization, as they represented $51 \%$, $45 \%$ and $21 \%$ of remineralization rates computed for oxygen, DIC and nitrate, respectively.

Shallow remineralization rates computed for ESTOC were significantly higher than at BATS for oxygen $\left(-3.9 \pm 1.0 \mathrm{~mol} \mathrm{O}_{2} \mathrm{~m}^{-2}\right)$ but showed no significant differences for DIC $\left(1.53 \pm 0.43 \mathrm{~mol} \mathrm{C} \mathrm{m}^{-2}\right)$ and nitrate $(38 \pm$ $155 \mathrm{mmol} \mathrm{N} \mathrm{m}^{-2}$ ). The latter was associated with large errors. The change in the tracer inventories underestimated remineralization rates for oxygen and DIC as represented 17 and $36 \%$ of these rates. However, nitrate remineralization rate was overestimated $(340 \%)$ by the change in the inventory.

Diffusion was a source for oxygen and a sink for DIC and nitrate in both stations because oxygen (DIC/nitrate) gradient was negative (positive) downwards and greater at $110 \mathrm{~m}$ than $250 \mathrm{~m}$. Vertical advection was a source for all the tracers at BATS because $w$ was negative at $110 \mathrm{~m}$ and zero at $250 \mathrm{~m}$, whereas it was a sink at ESTOC because upwelling was dominant during the investigation period. Lateral transport (geostrophic horizontal advection) was a source (sink) for oxygen (nitrate/DIC) at BATS and a source (sink) for oxygen and nitrate (DIC) at ESTOC. The divergence of the lateral transport of oxygen caused the differences in the remineralization rates computed for both stations, as the 1-D model without geostrophic advection resulted in oxygen consumption rates to be reduced by $61 \%$ at ESTOC $\left(-1.51 \pm 0.29 \mathrm{~mol} \mathrm{O}_{2} \mathrm{~m}^{-2}\right)$ and only by $27 \%$ at BATS $\left(-1.31 \pm 0.80 \mathrm{~mol} \mathrm{O}_{2} \mathrm{~m}^{-2}\right)$. The input of nitrate through lateral advection was also responsible for the low remineralization rate and the large error computed for nitrate at ESTOC, as the 1-D model computed a higher rate and lower associated error $\left(135 \pm 23 \mathrm{mmol} \mathrm{N} \mathrm{m}^{-2}\right)$. The fact that differences in remineralization rates between both stations were only statistically significant for oxygen could be 

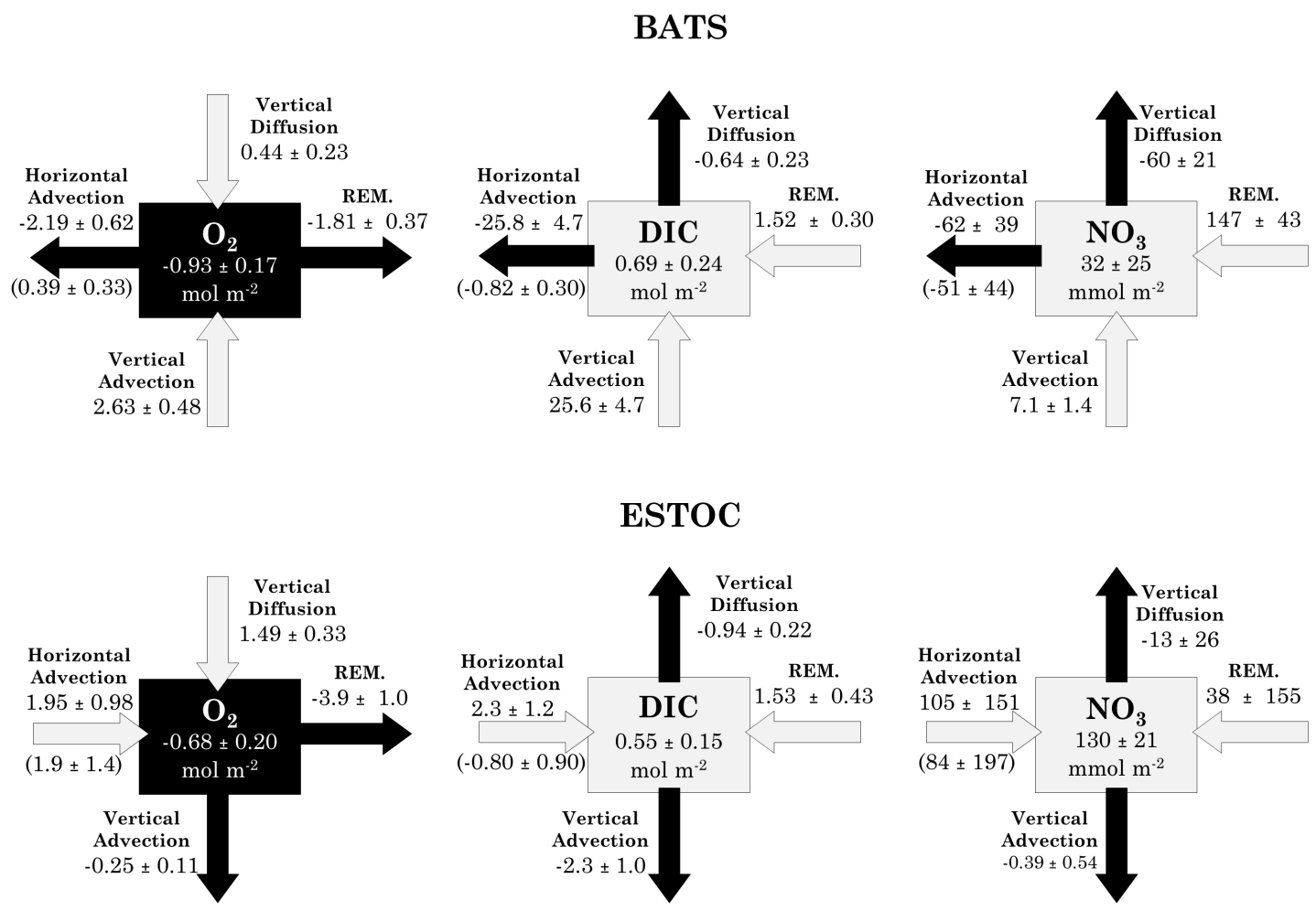

Fig. 9. Integrated model terms computed from $110 \mathrm{~m}$ down to $250 \mathrm{~m}$, and from April to December. REM is remineralization. Integrated geostrophic horizontal advection term is shown in brackets. White (black) arrows and boxed represent net gain (lost). Rates are expresed in mol $\mathrm{m}^{-2}$ for oxygen and DIC and in $\mathrm{mmol} \mathrm{m}^{-2}$ for nitrate.

related to the different temporal resolution of the databases used to compute the lateral gradients of the tracers. Oxygen and nitrate horizontal gradients were calculated from the World Ocean Atlas 2009 monthly climatology, whereas DIC gradients were obtained from the Global Distribution of Total Inorganic Carbon and Total Alkalinity Below the Deepest Winter Mixed Later Depths climatology, which includes lower temporal resolution tri-monthly averaged data (see Sect. 3.2.1). Model results show that inconsistencies in remineralization rates differences between the tracers decreased if oxygen and nitrate variability was reduced through smoothing (data not shown). Large errors associated to nitrate remineralization were probably due to the lower number of observations used to compute the nitrate, compared to oxygen, climatology.

Remineralization rates computed at BATS were comparable with previous estimates reported in the region (see Table 2). Jenkins and Goldman (1985) calculated the shallow (100-250 m) oxygen consumption rate between April and November at station $S$ in the Sargasso Sea to be $3 \mathrm{~mol} \mathrm{O}_{2} \mathrm{~m}^{-2}$. Sarmiento et al. (1990) summarized remineralization rates determined from a variety of tracer-based techniques in the Sargasso Sea to be $0.6-3.3 \mathrm{~mol} \mathrm{O}_{2} \mathrm{~m}^{-2}$ $\mathrm{yr}^{-1}$. Carlson et al. (1994) estimated the remineralization of dissolved organic matter from spring to fall as 0.99
$1.21 \mathrm{~mol} \mathrm{C} \mathrm{m}^{-2}$, which was lower than our estimate as it did not include the particulate organic fraction.

To our knowledge, geochemical estimates of shallow remineralization based on tracer distributions have not been conducted at ESTOC so far. Alonso-González et al. (2009) used a box model approach to calculate the lateral transport and consumption of suspended particulate organic matter (POC) in the Canary Current region. They found that lateral POC fluxes, which were up to 3 orders of magnitude higher than vertical fluxes, accounted for $1.42 \mathrm{mmol} \mathrm{C} \mathrm{m}^{-2}$ $\mathrm{d}^{-1}$, what represents $28-59 \%$ of the total mesopelagic (100$700 \mathrm{~m}$ ) respiration. The total carbon consumption estimated for mesopelagic waters in the fall was $2.4-5.1 \mathrm{mmol} \mathrm{C} \mathrm{m}^{-2}$ $\mathrm{d}^{-1}$, slightly lower than our estimate $\left(6.7 \pm 1.9 \mathrm{mmol} \mathrm{C} \mathrm{m}^{-2}\right.$ $\mathrm{d}^{-1}$ ) and one order of magnitude lower than respiration rates obtained during the summer, by using combined in vitro oxygen consumption and enzymatic activity techniques $\left(68 \mathrm{mmol} \mathrm{C} \mathrm{m}^{-2} \mathrm{~d}^{-1}\right)$ in the subtropical Northeast Atlantic (Arístegui et al., 2005). Alonso-González et al. hypothesized that this mismatch could be due to the different times of the year when the experiments were carried out. However, recent studies indicate that long incubations may lead to overestimations of community respiration as a result of an increase in the activity of heterotrophic bacteria (Marañón et al., 2007; Calvo-Díaz et al., 2011). Due to the differences in integration 
Table 2. Summary for remineralization estimates at BATS and ESTOC. AOU is apparent oxygen utilization; DOC, dissolved organic carbon; POC, particulate organic carbon; ETS, electron transport system and OC is organic carbon.

\begin{tabular}{|c|c|c|c|c|c|}
\hline Region & Source & Technique & Period & $\begin{array}{l}\text { Depths } \\
\mathrm{m}\end{array}$ & $\begin{array}{l}\text { Estimate } \\
\mathrm{mol} \mathrm{m}^{-2}\end{array}$ \\
\hline Sargasso Sea & Jenkins and Goldman (1985) & AOU seasonal cycle & Apr-Nov & $100-250$ & $3.0\left(\mathrm{O}_{2}\right)$ \\
\hline Sargasso Sea & Sarmiento et al. (1990) & Tracer Distribution & Annual & $100-250$ & $0.6-3.3\left(\mathrm{O}_{2}\right)$ \\
\hline BATS & Carlson et al. (1994) & DOC changes & Apr-Nov & $100-250$ & $0.99-1.21(\mathrm{C})$ \\
\hline BATS & from Helmke et al. (2010) & POC Fluxes & Spring-Fall & $110-250$ & $0.38(\mathrm{C})$ \\
\hline \multirow[t]{3}{*}{ BATS } & Ono et al. (2001) & Tracer Model & Apr-Dec & $100-250$ & $2.08 \pm 0.38\left(\mathrm{O}_{2}\right)$ \\
\hline & & & & $100-250$ & $1.53 \pm 0.35(\mathrm{C})$ \\
\hline & & & & $100-250$ & $0.080 \pm 0.046(\mathrm{~N})$ \\
\hline \multirow[t]{3}{*}{ BATS } & This study & Tracer Model & Apr-Dec & $110-250$ & $1.81 \pm 0.37\left(\mathrm{O}_{2}\right)$ \\
\hline & & & & & $1.52 \pm 0.30(\mathrm{C})$ \\
\hline & & & & & $0.147 \pm 0.043(\mathrm{~N})$ \\
\hline ESTOC & from Helmke et al. (2010) & POC fluxes & Spring-Fall & $110-250$ & $0.08(\mathrm{C})$ \\
\hline \multirow[t]{4}{*}{ ESTOC } & This Study & Tracer Model & Apr-Dec & $110-250$ & $3.9 \pm 1.0\left(\mathrm{O}_{2}\right)$ \\
\hline & & & & & $1.53 \pm 0.43(\mathrm{C})$ \\
\hline & & & & & $0.04 \pm 0.16(\mathrm{~N})$ \\
\hline & & & & & $\mathrm{mmol} \mathrm{m}^{-2} \mathrm{~d}^{-1}$ \\
\hline Canary Current & Arístegui et al. (2003) & ETS Activity & August & $200-1000$ & $7(\mathrm{C})$ \\
\hline Canary Current & Arístegui et al. (2005) & $\mathrm{ETS} / \mathrm{O}_{2}$ in vitro & Summer & $200-1000$ & $68(\mathrm{C})$ \\
\hline Canary Current & Alonso-González et al. (2009) & OC balance & Fall & $100-700$ & $2.4-5.1(\mathrm{C})$ \\
\hline
\end{tabular}

depths, comparison with these studies must be done carefully.

Shallow remineralization rates computed by our model can also be compared to particulate organic matter attenuation flux computed from sediment traps deployed at BATS and ESTOC. Comparative information for sediment traps for both stations corresponds to 150, 200 and $300 \mathrm{~m}$ at BATS and 200, 300 and $500 \mathrm{~m}$ at ESTOC (Helmke et al., 2010). In order to estimate remineralization rates between 110 and $250 \mathrm{~m}$, the particle flux at 110 and $250 \mathrm{~m}$ needs to be inferred. The former was calculated using the Martin's attenuation equation (Martin et al., 1987), considering the seasonal $b$ exponents calculated by Helmke et al. (2010) $(b=0.6-$ 1.19) for BATS, and the value reported by Neuer et al. (2007) $(b=0.81)$ for ESTOC. The particulate flux at $250 \mathrm{~m}$ was calculated by linearly interpolating the flux measured at 200 and $300 \mathrm{~m}$. Shallow remineralization computed from springtime to fall was $0.38 \mathrm{~mol} \mathrm{C} \mathrm{m}^{-2}$ at BATS and $0.08 \mathrm{~mol} \mathrm{C} \mathrm{m}^{-2}$ at ESTOC. Both values were lower than our estimates, which included the dissolved and particulate organic fractions, and represented 25 and $5 \%$ of the carbon remineralization computed for BATS and ESTOC, respectively. The sum of the remineralization rates of particulate and dissolved organic matter at BATS $\left(1.37-1.59 \mathrm{~mol} \mathrm{C} \mathrm{m}^{-2}\right)$ matches our estimation of carbon remineralization $\left(1.52 \pm 0.30 \mathrm{~mol} \mathrm{C} \mathrm{m}^{-2}\right)$. Unfortunately, no information about the seasonal variability of the dissolved organic carbon cycle is available at ESTOC.

Our results indicated that lateral transport is significant to the seasonality of the hydrodynamic conditions and the tracer distribution at ESTOC. Previous studies indicated that higher remineralization in the subtropical Northeast Atlantic could be supported by dissolved (Álvarez-Salgado et al., 2007) and slow sinking particulate organic matter (AlonsoGonzález et al., 2009) exported from the high productive African coastal upwelling, and also by dark dissolved inorganic carbon fixation (Baltar et al., 2010). In this respect, Arístegui et al. (2003) estimated that the contribution of dissolved organic carbon to the mesopelagic oxygen consumption in the Canary Current region was about $30 \%$. AlonsoGonzález et al. (2009) indicated that the reported differences in the carbon export rates between both stations could be, at least partially, explained by lower sedimentation rates of the particulate organic matter in the eastern part of the gyre, as slow-sinking or suspended POC does not accumulate in the sediment traps and can be laterally advected (Arístegui et al., 2009). Although organic matter was not explicitly taken into account in our model, our results support this hypothesis as they show stronger lateral transport and higher remineralization rates for oxygen at ESTOC, which cannot be sustained by the flux of sinking organic matter.

According to our results, shallow remineralization represents at BATS $54 \pm 33 \%$ and $51 \pm 36 \%$ of the net production computed in the photic zone for oxygen and DIC, respectively; whereas at ESTOC it represents $151 \pm 99 \%$ and $43 \pm 15 \%$ respectively. The high value for oxygen at ESTOC is related to the strong lateral inputs computed in the fall (see oxygen geostrophic horizontal advection in Fig. 6), which also resulted in negative net production computed during 
these months (see oxygen biological source in Fig. 6), suggesting that high remineralization rates could partially be sustained by non-locally produced organic matter.

The $-\mathrm{O}_{2}$ : C ratio for the shallow remineralization computed at BATS $(1.19 \pm 0.34)$ was in good agreement with the Redfield ratio (1.43), whereas at ESTOC $(2.52 \pm 0.98)$ was slightly higher. $\mathrm{C}: \mathrm{N}$ ratios were in excess of the Redfield ratio at both stations, and were higher at ESTOC $(40 \pm 162)$ than at BATS (10.2 \pm 3.6$)$, pointing to the export of carbon enriched organic matter. The $\mathrm{C}: \mathrm{N}$ ratio reported by Ono et al. (2001) for BATS $(19 \pm 12)$ was twice our estimate as a consequence of the differences in nitrate remineralization estimates. The higher $\mathrm{C}: \mathrm{N}$ ratio computed for ESTOC was consistent with the carbon rich organic matter observed in the mixed layer (Koeve, 2006) and the sinking organic matter (Neuer et al., 2007) in the region, and with close to Redfield ratios observed in the sinking organic matter at BATS (Schnetzer and Steinberg, 2002). Moreover, ecological models employed to study the sensitivity of carbon export to atmospheric nitrogen inputs in NASW and NASE showed higher $\mathrm{C}: \mathrm{N}$ values in the sinking organic matter in NASE (Mouriño-Carballido et al., 2012).

\section{Conclusions}

Subtropical gyres play a crucial role in the global carbon cycle due to the large extension they occupy which is expected to get bigger as a consequence of global warming (Polovina et al., 2008). Understanding the heterogeneity of these biomes is critical to comprehend the role of the oceans in the future carbon cycle. By using a 1-D diagnostic tracer model we investigated if potential differences in net production and shallow remineralization are consistent with the lower export of particulate organic carbon observed at the eastern (ESTOC) compared to the western side (BATS), of the North Atlantic Subtropical gyre. Our results showed slighly higher net production rates computed for oxygen and dissolved inorganic carbon at BATS, although the differences were not statistically significant. As our approach does not estimate mixed-layer net production, particularly during the winterspring bloom period, we cannot discard that it underestimates the differences in net production between the two stations. Shallow remineralization rate based on oxygen consumption was significantly higher at ESTOC. The comparison of our estimates with vertical fluxes of POC shows that, whereas a significant fraction $(25 \%)$ of the shallow remineralization is sustained by sinking organic matter at BATS, this fraction is much lower at ESTOC (5\%). The importance of horizontal processes in the seasonal cycles at ESTOC indicates that oxygen consumption at this station could be also supported by allochthonous inputs of organic matter. There is still work to be done to fully understand the mechanisms behind the regional differences observed in the vertical export of carbon at the North Atlantic subtropical gyre. In light of this and other studies, it seems that crucial information must come from the study of horizontal fluxes at ESTOC.

Acknowledgements. We are grateful to all the technicians and crew members involved in the collection, preparation, and analysis of the large data sets used in this study, in particular those from the BATS and ESTOC programs. B. Mouriño was supported by the Ramón y Cajal program from the Spanish Minister of Science and Technology. Funding for this study was provided by the Xunta de Galicia under the research project VARITROP (09MDS001312PR, PI B. Mouriño) and by the Ministerio de Ciencia e Innovation MOMAC project (CTM2008-05914/MAR). We would also like to thank the two reviewers for their help to improve the manuscript.

Edited by: G. Herndl

\section{References}

Alonso-González, I. J., Arístegui, J., Vilas, J. C., and HernándezGuerra, A.: Lateral POC transport and consumption in surface and deep waters of the Canary Current region: A box model study, Global Biogeochem. Cy., 23, GB2007, doi:10.1029/2008GB003185, 2009.

Álvarez-Salgado, X. A., Arístegui, J., Barton, E. D., and Hansell, D. A.: Contribution of upwelling filaments to offshore carbon export in the subtropical Northeast Atlantic Ocean, Limnol. Oceanogr., 52, 1287-1292, 2007.

Antonov, J. I., Seidov, D., Boyer, T. P., Locarni, R. A., Mishonov, A. V., Garcia, H. E., Baranova, O. K., Zweng, M. M., and Johnson, D. R.: World Ocean Atlas 2009, Volume 2: Salinity., Ed. NOAA Atlas NESDIS 69, US Government Printing Office, Washington, DC, 2010.

Arístegui, J., Barton, E., Montero, M., García-Muñoz, M., and Escánez, J.: Organic carbon distribution and water column respiration in the NW Africa-Canaries Coastal Transition Zone, Aquat. Microb. Ecol., 33, 289-301, 2003.

Arístegui, J., Duarte, C. M., Gasol, J. M., and Alonso-Sáez, L.: Active mesopelagic prokaryotes support high respiration in the subtropical northeast Atlantic Ocean, Geophys. Res. Lett., 32, L03608, doi:10.1029/2004GL021863, 2005.

Arístegui, J., Gasol, J. M., Duarte, C. M., and Herndl, G. J.: Microbial oceanography of the dark ocean's pelagic realm, Limnol. Oceanogr., 54, 1501-1529, doi:10.4319/lo.2009.54.5.1501, 2009.

Baltar, F., Arístegui, J., Sintes, E., Gasol, J. M., Reinthaler, T., and Herndl, G. J.: Significance of non-sinking particulate organic carbon and dark $\mathrm{CO} 2$ fixation to heterotrophic carbon demand in the mesopelagic northeast Atlantic, Geophys. Res. Lett, 37, L09602, doi:10.1029/2010GL043105, 2010.

Bonnet, S., Grosso, O., and Moutin, T.: Planktonic dinitrogen fixation along a longitudinal gradient across the Mediterranean Sea during the stratified period (BOUM cruise), Biogeosciences, 8 , 2257-2267, doi:10.5194/bg-8-2257-2011, 2011.

Brix, H., Gruber, N., Karl, D. M., and Bates, N. R.: On the relationships between primary, net community, and export production in subtropical gyres, Deep Sea. Res. Pt. II, 53, 698-717, 2006.

Calvo-Díaz, A., Díaz-Pérez, L., G Morán, X. A., Teira, E., and Marañón, E.: Bottle enclosure causes a decrease in the au- 
totrophic to heterotrophic biomass ratio of picoplankton in oligotrophic marine waters, Appl. Environ. Microb., 77, 5739-5746 2011.

Capone, D. G., Burns, J. A., Montoya, J. P., Subramaniam, A., Mahaffey, C., Gunderson, T., Michaels, A. F., and Carpenter, E. J.: Nitrogen fixation by Trichodesmium spp.: An important source of new nitrogen to the tropical and subtropical North Atlantic Ocean, Global Biogeochem. Cy., 19, GB2024, doi:10.1029/2004GB002331, 2005.

Carlson, C. A., Ducklow, H. W., and Michaels, A. F.: Annual flux of dissolved organic carbon from the euphotic zone in the northwestern Sargasso Sea, Nature, 371, 405-408, doi:10.1038/371405a0, 1994.

Cianca, A., Helmke, P., Mouriño, B., Rueda, M. J., LLinás, O., and Neuer, S.: Decadal analysis of hydrography and in situ nutrient budgets in the western and eastern North Atlantic subtropical gyre, J. Geophys. Res.-Oceans, 112, C07025, doi:10.1029/2006JC003788, 2007.

Davenport, R., Neuer, S., Helmke, P., Perez-Marrero, J., and LLinás, O.: Primary productivity in the northern Canary Islands region as inferred from SeaWiFS imagery, Deep-Sea Res. Pt. II, 49, 34813496, doi:10.1016/S0967-0645(02)00095-4, 2002.

Emerson, S., Quay, P., Karl, D., Winn, C., Tupas, L., and Landry, M.: Experimental determination of the organic carbon flux from open-ocean surface waters, Nature, 389, 951-954, 1997.

Field, C. B., Behrenfeld, M. J., Randerson, J. T., and Falkowski, P.: Primary Production of the Biosphere: Integrating Terrestrial and Oceanic Components, Science, 281, 237-240, doi:10.1126/science.281.5374.237, 1998.

Fofonoff, N. P. and Millard, R. C.: Algorithms for computation of fundamental properties of seawater, Unesco Technical Papers in Marine Science, 44, 53, 1983.

Garcia, H. E., Locarnini, R. A., Boyer, T., Antonov, J. I., Zweng, M., and Johnson, D. R.: World Ocean Atlas 2009, Volume 4: Nutrients (phosphate, nitrate, silicate), NOAA Atlas NESDIS 71, US Government Printing Office, Washington, DC, 2010a.

Garcia, H. E., Locarnini, R. A., Boyer, T., Antonov, J. I., Zweng, M., and Johnson, D. R.: World Ocean Atlas 2009, Volume 3: Dissolved Oxygen, Apparent Oxygen Utilization, and Oxygen Saturation., NOAA Atlas NESDIS 70, US Government Printing Office, Washington, DC, 2010b.

González-Dávila, M., Santana-Casiano, J. M., Rueda, M.-J., Llinás, O., and González-Dávila, E.-F.: Seasonal and interannual variability of sea-surface carbon dioxide species at the European Station for Time Series in the Ocean at the Canary Islands (ESTOC) between 1996 and 2000, Global Biogeochem. Cy., 17, 1076, doi:10.1029/2002GB001993, 2003.

González-Dávila, M., Santana-Casiano, J. M., and GonzálezDávila, E. F.: Interannual variability of the upper ocean carbon cycle in the northeast Atlantic Ocean, Geophys. Res. Lett., 34, L07608, doi:10.1029/2006GL028145, 2007.

González-Dávila, M., Santana-Casiano, J. M., Rueda, M. J., and Llinás, O.: The water column distribution of carbonate system variables at the ESTOC site from 1995 to 2004, Biogeosciences, 7, 3067-3081, doi:10.5194/bg-7-3067-2010, 2010.

Goyet, C., Healy, R., and Ryan, J.: Global distribution of total inorganic carbon and total alkalinty below the deepest winter mixed layer depths, Environmental Sciences Division, US Department of Energy, 2000.
Gruber, N.: Nitrogen in the Marine Environment, chap. The marine nitrogen cycle: overview and challenges, 1-50, Academic Press, Elsevier Inc., Amsterdam., 2008.

Gruber, N., Keeling, C. D., and Stocker, T. F.: Carbon-13 constraints on the seasonal inorganic carbon budget at the BATS site in the northwestern Sargasso Sea, Deep-Sea Res. Pt. I, 45, 673-717, 1998.

Helmke, P., Neuer, S., Lomas, M. W., Conte, M., and Freudenthal, T.: Cross-basin differences in particulate organic carbon export and flux attenuation in the subtropical North Atlantic gyre, DeepSea Res. Pt. I, 57, 213-227, doi:10.1016/j.dsr.2009.11.001, 2010.

Jenkins, W. and Goldman, J.: Seasonal oxygen cycling and primary production in the Sargasso Sea, J. Mar. Res., 43, 465-491, 1985.

Koeve, W.: C:N stoichiometry of the biological pump in the North Atlantic: Constraints from climatological data, Global Biogeochem. Cy., 20, GB3018, doi:10.1029/2004GB002407, 2006.

Leetmaa, A. and Bunker, A. F.: Updated charts of the mean annual wind stress, convergences in Ekman Layers, and Sverdrup transport in the North Atlantic, J. Mar. Res., 36, 311-322, 1978.

Lipschultz, F., Bates, N., Carlson, C., and Hansell, D.: New production in the Sargasso Sea: History and current status, Global Biogeochem. Cy., 16, 1001, doi:10.1029/2000GB001319, 2002.

Locarnini, R. A., Mishonov, A. V., Antonov, J. I., Boyer, T., Garcia, H., Baranova, O. K., Zweng, M. M., and Johnson, D. R.: World Ocean Atlas 2009, Volume 1: Temperature, NOAA Atlas NESDIS 68, US Government Printing Office, Washington, DC, 2010.

Marañón, E., Pérez, V., Fernández, E., Anadón, R., Bode, A., González, N., Huskin, I., Isla, A., Morán, X. A. G., Mouriño, B., Quevedo, M., Robinson, C., Serret, P., Teira, E., Varela, M. M., Woodward, E. M. S., and Zubkov, M. V.: Planktonic carbon budget in the eastern subtropical North Atlantic, Aquat. Microb. Ecol., 48, 261-275, 2007.

Marañón, E., Fernández, A., Mouriño-Carballido, B., MartínezGarcía, S., Teira, E., Cermeño, P., Chouciño, P., Huete-Ortega, M., Fernández, E., Calvo-Díaz, A., Morán, X. A. G., Bode, A., Moreno-Ostos, E., Varela, M. M., Patey, M. D., and Achterberg, E. P.: Degree of oligotrophy controls the response of microbial plankton to Saharan dust, Limnol. Oceanogr., 55, 2339-2352, 2010.

Marchal, O., Monfray, P., and Bates, N. R.: Spring summer imbalance of dissolved inorganic carbon in the mixed layer of the northwestern Sargasso Sea, Tellus B-Chem. Phys. Meteorol., 48, 115-134, 1996.

Martin, J. H., Knauer, G. A., Karl, D. M., and Broenkow, W. W.: VERTEX: carbon cycling in the northeast Pacific, Deep-Sea Res. Pt. A., 34, 267-285, 1987.

Menzel, D. and Ryther, J.: The annual cycle of primary production in the Sargasso Sea off Bermuda, Deep-Sea Res., 6, 351-367, 1959.

Michaels, A. F. and Knap, A. H.: Overview of the U.S. JGOFS Bermuda Atlantic Time-series Study and the Hydrostation S program, Deep-Sea Res. Pt. II, 43, 157-198, 1996.

Millero, F. J. and Poisson, A.: International one-atmosphere equation of state of seawater, Deep-Sea Res. Pt. A, 28, 625-629, 1981.

Mouriño, B., Fernández, E., Etienne, H., Hernández, F., and Giraud, S.: Significance of cyclonic SubTropical Oceanic Rings of Magnitude (STORM) eddies for the carbon budget of the euphotic layer in the subtropical northeast Atlantic, J. Geophys. Res., 108, 
3383, doi:10.1029/2003JC001884, 2003.

Mouriño-Carballido, B. and Anderson, L. A.: Net community production of oxygen derived from in vitro and in situ 1-D modeling techniques in a cyclonic mesoscale eddy in the Sargasso Sea, Biogeosciences, 6, 1799-1810, doi:10.5194/bg-61799-2009, 2009.

Mouriño-Carballido, B. and Neuer, S.: Regional Differences in the Role of Eddy Pumping in the North Atlantic Subtropical Gyre: Historical conundrums revisited, Oceanography, 21, 5261, 2008.

Mouriño-Carballido, B., Marañón, E., Fernández, A., Graña, R., Bode, A., Varela, V., Domínguez, F., Escánez, J., and de Armas, D.: Importance of N2 fixation versus nitrate eddy diffusion across the Atlantic Ocean, Limnol. Oceanogr., 56, 999-1007, 2011.

Mouriño-Carballido, B., Pahlow, M., and Oschlies, A.: High sensitivity of ultra-oligotrophic marine ecosystems to atmospheric nitrogen deposition, Geophys. Res. Lett., 39, L05601, doi:10.1029/2011GL050606, 2012.

Musgrave, D. L., Chou, J., and Jenkins, W. J.: Application of a Model of Upper-Ocean Physics for Studying Seasonal Cycles of Oxygen, J. Geophys. Res, 93, 15679-15700, 1988.

Najjar, R. G. and Keeling, R. F.: Mean annual cycle of the air-sea oxygen flux: A global view, Global Biogeochem. Cy., 14, 573584, 2000.

Neuer, S., Davenport, R., Freudenthal, T., Wefer, G., LLinás, O., Rueda, M., Steinberg, D., and Karl, D.: Differences in the biological carbon pump at three subtropical ocean sites, Geophys. Res. Lett., 29, 1885, doi:10.1029/2002GL015393, 2002a.

Neuer, S., Freudenthal, T., Davenport, R., Llinás, O., and Rueda, M.-J.: Seasonality of surface water properties and particle flux along a productivity gradient off NW Africa, Deep-Sea Res. Pt. II, 49, 3561-3576, 2002b.

Neuer, S., Torres-Padron, M., Gelado-Caballero, M., Rueda, M., Hernández-Brito, J., Davenport, R., and Wefer, G.: Dust deposition pulses to the eastern subtropical North Atlantic gyre: Does ocean's biogeochemistry respond?, Global Biogeochem. Cy., 18, GB4020, doi:10.1029/2004GB002228, 2004.

Neuer, S., Cianca, A., Helmke, P., Freudenthal, T., Davenport, R., Meggers, H., Knoll, M., Santana-Casiano, J. M., GonzálezDávila, M., Rueda, M.-J., and LLinás, O.: Biogeochemistry and hydrography in the eastern subtropical North Atlantic gyre. Results from the European time-series station ESTOC, Progr. Oceanogr., 72, 1-29, doi:10.1016/j.pocean.2006.08.001, 2007.

Ono, S., Ennyu, A., Najjar, R. G., and Bates, N. R.: Shallow remineralization in the Sargasso Sea estimated from seasonal variations in oxygen, dissolved inorganic carbon and nitrate, DeepSea Res. Pt. II, 48, 1567-1582, 2001.
Pätsch, J., Kühn, W., Radach, G., Santana Casiano, J. M., Gonzalez Davila, M., Neuer, S., Freudenthal, T., and LLinás, O.: Interannual variability of carbon fluxes at the North Atlantic Station ESTOC, Deep-Sea Res. Pt. II, 49, 253-288, 2002.

Paulson, C. A. and Simpson, J. J.: Irradiance Measurements in the Upper Ocean, J. Phys. Oceanogr, 7, 952-956, 1977.

Pelegrí, J., Arístegui, J., Cana, L., González-Dávila, M., HernándezGuerra, A., Hernández-León, S., Marrero-Díaz, A., Montero, M., Sangrà, P., and Santana-Casiano, M.: Coupling between the open ocean and the coastal upwelling region off northwest Africa: water recirculation and offshore pumping of organic matter, J. Mar. Syst., 54, 3-37, 2005.

Polovina, J. J., Howell, E. A., and Abecassis, M.: Ocean's least productive waters are expanding, Geophys. Res. Lett, 35, L03618, doi:10.1029/2007GL031745, 2008.

Pulido-Villena, E., Wagener, T., and Guieu, C.: Bacterial response to dust pulses in the western Mediterranean: Implications for carbon cycling in the oligotrophic ocean, Global Biochem. Cy., 22, GB1020, doi:10.1029/2007GB003091, 2008.

Riser, S. C. and Johnson, K. S.: Net production of oxygen in the subtropical ocean, Nature, 451, 323-U5, doi:10.1038/nature06441, 2008.

Santana-Casiano, J. M., González-Dávila, M., Rueda, M.-J., Llinás, O., and González-Dávila, E.-F.: The interannual variability of oceanic $\mathrm{CO}_{2}$ parameters in the northeast Atlantic subtropical gyre at the ESTOC site, Global Biogeochem. Cy., 21, GB1015, doi:10.1029/2006GB002788, 2007.

Sarmiento, J., Thiele, G., Key, R., and Moore, W.: Oxygen and nitrate new production and remineralization in the North-Atlantic Subtropical Gyre, J. Geophys. Res.-Oceans, 95, 18303-18315, 1990.

Schnetzer, A. and Steinberg, D. K.: Active transport of particulate organic carbon and nitrogen by vertically migrating zooplankton in the Sargasso Sea, Mar. Ecol.-Prog. Ser., 234, 71-84, doi:10.3354/meps234071, 2002.

Siegel, D. A. and Deuser, W. G.: Trajectories of sinking particles in the Sargasso Sea: modeling of statistical funnels above deepocean sediment traps, Deep-Sea Res. Pt. I, 44, 1519-1541, 1997.

Siegel, D. A., McGillicuddy, D. J., and Fields, E. A.: Mesoscale eddies, satellite altimetry, and new production in the Sargasso Sea, J. Geophys. Res., 104, 13359-13379, 1999.

Steinberg, D. K., Carlson, C. A., Bates, N. R., Johnson, R. J., Michaels, A. F., and Knap, A. H.: Overview of the US JGOFS Bermuda Atlantic Time-series Study (BATS): a decade-scale look at ocean biology and biogeochemistry, Deep-Sea Res. Pt. II, 48, 1405-1447, 2001. 